\title{
Rumors and Runs in Opaque Markets: Evidence from the Panic of 1907
}

\author{
Caroline Fohlin \\ Thomas Gehrig \\ Marlene Haas
}

\author{
CESIFO WORKING PAPER NO. 6048 \\ CATEGORY 7: MONETARY POLICY AND INTERNATIONAL FINANCE \\ August 2016
}

An electronic version of the paper may be downloaded

- from the SSRN website:

- from the RePEc website:

- from the CESifo website: WwW.SSRN.com

Www.RePEc.org

www.CESifo-group.org/wp 


\title{
Rumors and Runs in Opaque Markets: Evidence from the Panic of 1907
}

\begin{abstract}
Using a new daily dataset for all stocks traded on the New York Stock Exchange between 1905 and 1910, we study the impact of information asymmetry during the liquidity freeze and market run of October 1907 - one of the most severe financial crises of the 20th century. We estimate that the market run drove up spreads from $0.5 \%$ to $3 \%$ during the peak of the crisis and, using a spread decomposition, we identify information risk as the largest component of illiquidity. Information costs rose most in the mining sector - the origin of the stock corner and a sector with among the worst track records of corporate governance and accounting. We find other hallmarks of information-based illiquidity: trading volume dropped and price impact rose. Despite short-term cash infusions into the market, the market remained relatively illiquid for several months following the peak of the panic. Notably, market illiquidity risk is priced in the cross section of stock returns. Thus, our findings demonstrate how opaque systems allow idiosyncratic rumors to spread and amplify into a long-lasting, market-wide crisis.
\end{abstract}

JEL-Codes: G000, G140, N000, N200.

Keywords: microstructure, panic, information asymmetry, funding illiquidity, market illiquidity, fire sales, price discovery.

\author{
Caroline Fohlin \\ Emory University \\ USA - 30322-2240 Atlanta GA \\ cfohlin@emory.edu
}

\author{
Thomas Gehrig \\ University of Vienna / Austria \\ thomas.gehrig@univie.ac.at
}

\author{
Marlene Haas \\ University of Vienna / Austria \\ marlene.haas@vgsf.ac.at
}

\section{August 5, 2016}

This material is based upon work supported by the U.S. National Science Foundation under Grant No. 0850576 to Fohlin and upon a TransCoop Grant by the Alexander-von-Humboldt Foundation to Gehrig. We are grateful to Floris Daverveldt and Caitlin McDonald for extensive research assistance. The paper greatly benefited from discussions with and comments from Giuseppe Bertola, Martin Boyer, Tarun Chordia, Hans Degryse, Ester Faja, Valentin Haddad, Nikolaus Hautsch, Stefan Lutz, Giovanna Nicodano, David Jacho-Chavez, Nobuhiro Kiyotaki, Albert S. Kyle, Kebin Ma, Georg Kirchsteiger, Roland Mestel, Paul Mizon, Carol Osler, Marco Pagano, Klaus Ritzberger, Mary Rodgers, Karl Schlag, Isabel Schnabel, Ellis Tallmann, and Joseph Zechner. We are grateful for comments and suggestions from the participants of the University of Vienna Brown Bag Seminar, the 2014 VGSF Conference, the 2015 In_niti Conference, the 2015 CFA Institute Workshop on Financial History (Judge School of Management, Cambridge University), the 32nd Annual EALE Conference in Vienna, the 11th Annual Central Bank Conference on the Microstructure of Financial Markets in Dublin, the ÖFG-Conference on "Accounting, Information and Financial Crises" in Graz, the Econometric Society Session on "Financial Crises in Historical Perspective” at the ASSA 2016 meetings in San Francisco, the CEPR Spring Symposium at Imperial College in London, Bonn University seminar, and the University of Vienna seminar. All errors are our own. 


\section{Introduction}

The Panic of 1907 marked the beginning of the end of unregulated capital markets and weak central monetary authority in the United States. Much like the global financial crisis of 2008, the episode set off an immediate outcry from the public followed by reactions from federal and state governments. While private initiatives - notably, the concerted effort organized by John Pierpont Morgan - contributed to resolving the crisis, the depth and duration of the crisis, and its after effects, provided central banking advocates the ammunition they needed to push through the Federal Reserve Act, and in the meantime the provision of emergency currency via the Aldrich-Vreeland Act ${ }^{1}$. The crisis prompted the famous Money Trust hearings in Congress that led to the Clayton Antitrust Act, as well as a state level investigation in New York that ultimately led to tighter control over access to trading at the NYSE. These regulatory steps laid the foundation for the more far-reaching regulatory interventions, such as the U.S. Securities and Exchange Commission (SEC), that emerged during the Great Depression. ${ }^{2}$

Because it took place in an era of weak corporate governance law, highly variable accounting practices, and essentially no regulation of stock markets - all compounded by rudimentary information technology - traders faced a continual threat of informational contagion (e.g., Bernstein et al. (2014)) and difficulties in assessing counterparty risk (see Frydman et al. $\left.(2012)^{3}\right)$. In the environment of October 1907, market participants could only see a general decline in market prices, combined with plummeting United Copper stock prices and the failure of a major brokerage house, followed by news of illiquidity and then runs on several associated banks and trust companies and spikes in short term borrowing (call money) rates. This series of events stirred panic across the board, because both institutions and markets were opaque and information was difficult to verify.

The Panic of 1907 provides an opportunity to understand better how information problems impact the financial system, via liquidity in both banks and markets. Importantly, the Panic allows analysis of the impact of market forces with minimal regulatory friction. Most previous studies examine the panic at the aggregate level and at lower frequency and therefore cannot analyze microstructure effects - where the problem (and presumably, the solution) really lies. In contrast, we reveal a much more nuanced picture of the unfolding crisis by exploiting a new database of daily transaction, quotation, and volume data for

\footnotetext{
${ }^{1}$ Which would come into play in the summer of 1914 (Fohlin (2016)).

${ }^{2}$ This paper builds on an earlier study by Fohlin et al. (2008).

${ }^{3}$ See also Gorton (1988), Calomiris and Gorton (1991), and Moen and Tallman (1992) for earlier work.
} 
all stocks traded on the NYSE from 1905 to $1910 .{ }^{4}$ Based on this novel data set, we uncover a range of new results on funding and market liquidity and their interaction with asset pricing.

We start, in the next two sections, by describing our data set and examining the details of the crisis and the economic and institutional context in which it unfolded. We demonstrate that the stock market (the NYSE) showed signs of deteriorating liquidity - rising bid-ask spreads and price impact measures and declining volume - starting in September of 1907, in advance of the most acute period of crisis. Moreover, the heightened illiquidity lasted until March 1908, several months after the run ended. Next, we explore, in Section 4, the impact of the panic on funding illiquidity and demonstrate that funding illiquidity drove stock market illiquidity (spreads) during the peak of the crisis. We then move on in section 5 to demonstrate that traders priced in stock illiquidity risk, based on a four-factor asset pricing model.

After establishing the general impact of funding market and stock market illiquidity, we dig a bit deeper, in section 6, and test our hypothesis that opaqueness, and resulting information asymmetry, lay at the core of the problem. We undertake a decomposition of spreads and show that the adverse selection component dominates the other two spread components (inventory holding and order processing). We show further that stocks with the worst information opaqueness - mining stocks, unlisted stocks, and stocks with the highest spreads pre-Panic - have the greatest illiquidity and adverse selection component during the panic. Finally, in section 7, we refine the initial asset pricing analysis to show that informational risk is priced into stock returns. Section 8 concludes.

\section{Data Collection}

Understanding the 1907 financial crisis at a granular level, and connecting market illiquidity with funding illiquidity, requires high frequency data that has been, until now, unavailable to researchers. In order to provide this microstructure perspective, we use newly-gathered data on transaction prices (first, last, high, and low), closing bid and ask quotations, and volumes (number of shares traded) for all stocks trading on the NYSE on every trading day from 1905 through $1910 .^{5}$ An example of a stock quote from the New York Times can be found in Figure 1. The markets were open Monday through Saturday during this period, making for roughly 300 trading days per year. The raw data come

\footnotetext{
${ }^{4}$ See Fohlin (2015) for more detail on the larger data collection project.

${ }^{5}$ The data constitute a portion of the new NYSE database for 1900-1925 created by and discussed in greater detail in Fohlin (2016), funded by grants from the U.S. National Science Foundation.
} 
from the NYSE daily transactions table, printed the following day in the New York Times business pages. The newspaper images (Figure 1) are not machine readable, and optical character recognition (OCR) proved infeasible, so the data were all entered by hand, using double entry and cross checking. We then ran all data through logical error checking to spot any potential typographical errors in the source or inserted during data entry: for example, flagging negative spreads and 'high' and 'low' not the highest and lowest prices, respectively. We also checked any entries with relative bid-ask spread or daily return exceeding ten percent. The database covers all stocks, common and preferred, as well as rights, warrants and other related equity securities. In the current analysis, we concentrate on common stock, since it is the most prevalent and actively traded class.

\footnotetext{
Stock Quote 1 -- No Title
}

New York Times (1857-1922); Oct 18, 1907; ProQuest Historical Newspapers: The New York Times pg. 12

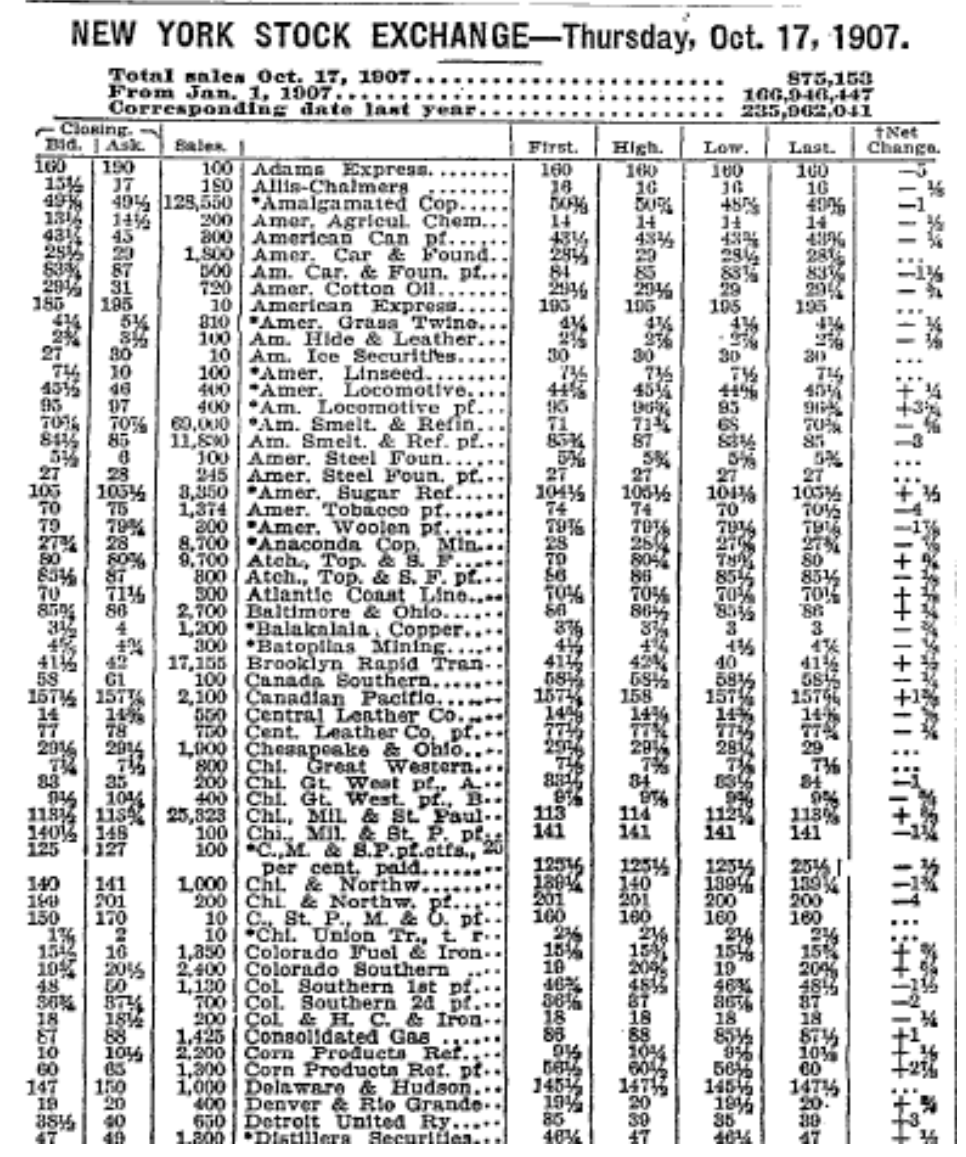

Figure 1: Example of Stock Quote from the New York Times (October 1907)

For every stock trading on the NYSE during the period, we gathered data on book value of common equity and par values of total capital in order to re-weight portfolios. These 
data come from the New York Times weekly financial supplement and Moody's Manual of Investments. Again, we excluded preferred stock data (following Fama and French (1993)).

In order to control for funding liquidity and riskless rates, we gathered both monthly U.S. call money rates and gold stock reserves (in billions of dollars) from the National Bureau of Economic Research Macro-history Database. ${ }^{6}$ Gold stock reserves proxies for the risk-free rate, since T-bills appeared much later. Call money is short-term inter-bank lending, typically secured by gold or stocks. In the period we analyze, the call money rate represents the marginal cost of financing for stock purchases. We also collected daily high and low call money rates from the New York Tribune for the time period of August 1, 1907, to May 31, 1908.

Table 1 provides descriptive statistics on the key variables: relative bid-ask spreads, number of shares traded, last, highest and lowest prices during a trading day ${ }^{7}$, quasi volatility, and call money rates. The median percentage bid-ask spread over the period was 0.8 percent, though a number of high spread stocks pulled the average up to two percent. Likewise, the median stock traded only 800 shares in a given day, but the handful of large firms traded orders of magnitude more. Thus, around 7,521 shares traded per company on an average trading day. The highest price and the lowest price were on average $\$ 75.48$ and $\$ 74.64$ with median values of $\$ 55.00$ and $\$ 54.00$, respectively. Call money rates averaged nine percent during August 1907 to June 1908, but the rate usually held steady at much lower levels, with a median rate of three percent. Table 1 also reports descriptive statistics of capital stock data and the book-to-market ratio. Companies were generally trading below par, with book-to-market ratios averaging 3.71 (median of 1.73). Table 2 reports descriptive statistics of the monthly variables: gold stock; the three components of relative spreads (adverse selection, inventory holding, and order processing). As we will discuss at greater length later, the adverse selection component contributed on average the most to relative spreads (50 percent), whereas the inventory and order processing component contributed about 25 percent each. Median values are similar in size. Gold stock averaged 1.5 billion Dollars during the period 1905-1910.

\footnotetext{
${ }^{6}$ According to this data source, call money rates data are smoothed by Macaulay's forty-three term graduation (See Burns et al. (1946), Chapter Eight). Source: Macaulay et al. (1938), Table 21, Col. 2. Gold stock reserves come from Federal Reserve Board, Banking And Monetary Statistics; Federal Reserve Bulletins.

${ }^{7}$ Note that the "last" price of the day could have taken place at any time, not necessarily at the close of the market.
} 


\section{The Panic in Context}

In basic terms, the NYSE operated in 1907 much as it does today: a continuous auction mechanism, in which transactions occur throughout the trading day, with no guarantee of a single price. Brokers traded on behalf of their customers and received set commissions as their payment, while specialists bought and sold shares in order to make markets in securities, and they received the bid-ask spread as their compensation. Specialists managed their trades at circular trading posts, equipped with telephones. The photograph in Figure 2, from Pearson's Magazine, depicts the trading floor in November of 1907, apparently shot covertly due to restrictions preventing photography of the trading floor at the time. Today's floor looks much the same, albeit with obvious modernization and technology (and fewer people). ${ }^{8}$

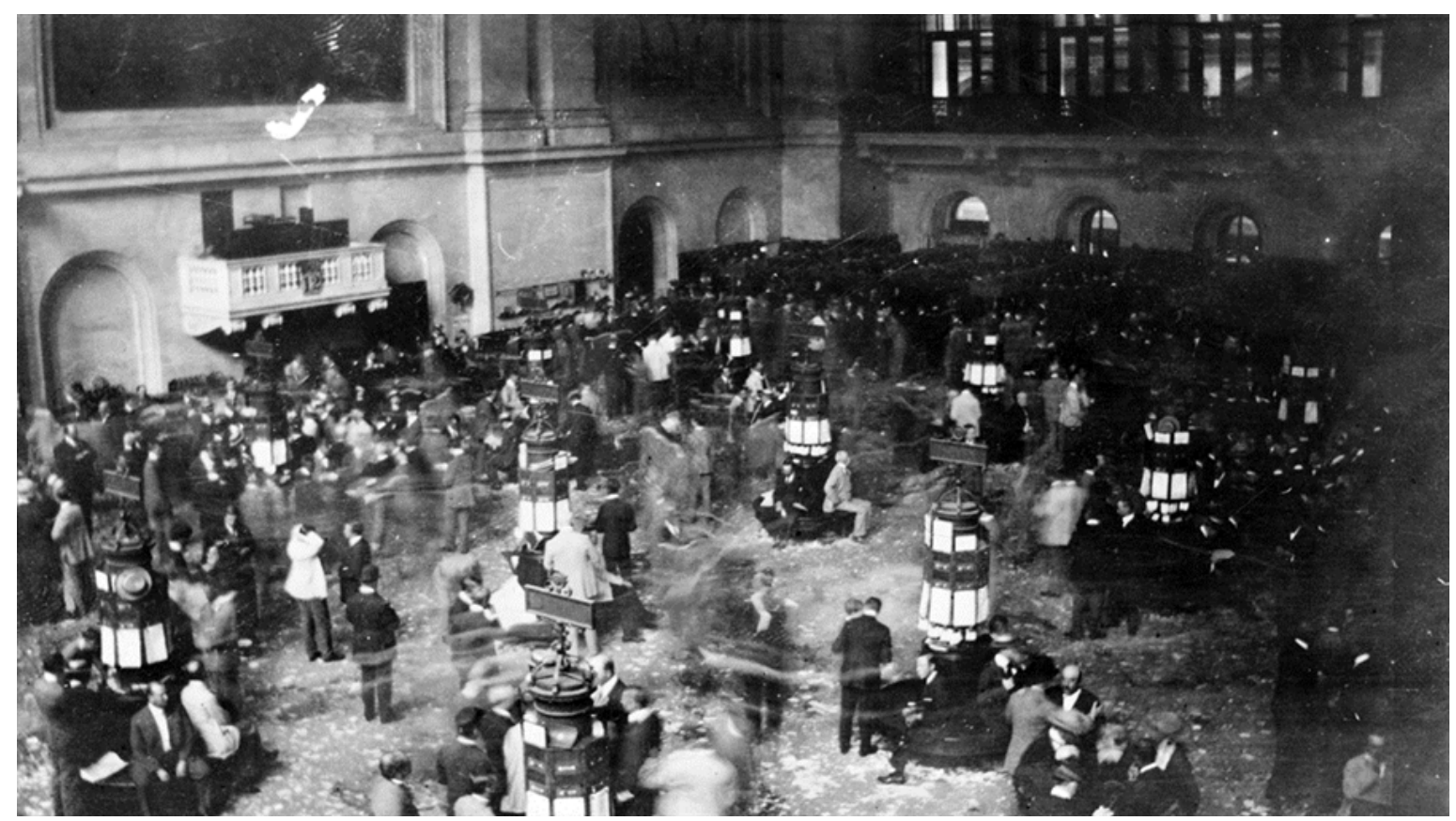

Figure 2: Historical Trading Floor

From its inception, and for most of its history, the NYSE was owned by its members and largely self-regulated. Among the key internal rules were those that dealt with membership. Joining the exchange was a costly venture: a new member had to pay a membership fee and then buy the seat of an existing member. The exchange had fixed the number of seats at 1,100 in 1879, so that the prices of seats varied with the market. Seat prices therefore varied considerably but grew fairly steadily and reached a local peak of $\$ 95,000$

\footnotetext{
${ }^{8}$ See "Historical trading floor" or Figure 2
} 
in the year before the crisis. $^{9}$ Notably, seats sold for as little as $\$ 51,000$ in the panic year and the year following. ${ }^{10}$ The Governing Committee of the exchange held ultimate responsibility for exchange operations and had the power to fine or even to expel members for infractions against exchange rules. The value of a member's seat worked as collateral in these cases or in the event of bankruptcy (Mulherin et al. (1991)). The courts upheld these powers as well as the exchanges' right to restrict trading solely to its members and to set other rules (Mulherin et al. (1991)).

The NYSE implemented relatively stringent listing standards and requirements, including registration of all shares (to prevent stock watering), minimum shareholder numbers, and a qualitative assessment of risk. Oil stocks, for example, could not be listed in their early years because they were deemed too risky.

Despite the similarities in organization (albeit with obvious technological innovations), financial markets circa 1907 differed considerably from today in their regulation. Weak (nearly non-existent) regulations over corporate governance and investor protections yielded persistent information opaqueness throughout the initial phases of development of the corporate economy and capital markets. In particular, corporate reporting law remained loose and vague in the United States until the Great Depression and the spate of disclosure regulations that followed.

Internal incentives and particularly the desire to access outside funds from investors encouraged a growing number of companies to publish their balance sheets and income statements, but the practice was far from widespread. The NYSE issued a recommendation in 1895 that listed companies providing both a balance sheet and an income statement in annual reports to investors. Such reporting then became mandatory in 1899. Still, the adherence to and enforcement of the rule remained weak for many years, and the content of these reports varied significantly in their extent and accuracy (Archambault and Archambault (2005) and Sivakumar and Waymire (1993)). In particular, companies in sectors subject to rate regulation saw the greatest incentive to publish their accounts, but their regulation also created incentives to manipulate their earnings statements (Archambault and Archambault (2011)). New laws and exchange rules requiring audited accounts developed only after the Panic of 1907 (Sivakumar and Waymire (1993) and Sivakumar and Waymire (2003)).

\footnotetext{
${ }^{9}$ In 2014 terms, equivalent to $\$ 1.8-\$ 2.5$ million, depending on the deflator used.

${ }^{10}$ Davis and Gallman (2001), page 320.
} 
Thus, notably, the rapid financial development that funneled large amounts of capital into New York had taken place in spite of poor legal protection for investors and sparse, erratic, and often non-existent or erroneous information on corporate performance. This opaque information environment exacerbated the growing uncertainty over stock valuations in the months before the crisis, most particularly in the mining sector. We can see the role of information as we track the events over the days leading up to the panic.

The basic facts of the Panic of 1907 are fairly clear. Stocks had been on a bull run for nearly two years, starting in late 1903, but weakness began to emerge in 1906 . After considerable declines in the market in March and August 1907 (see Figure 3) the poor sentiment turned to panic in October of 1907. The bear market targeted mining stocks, dominated by copper, most heavily. The mining stocks had risen in excess of the broader bull market in 1905 and early 1906 and then dropped more dramatically during the crisis and recovered the least after the crisis ended in 1908 (see Figure 4). ${ }^{11}$

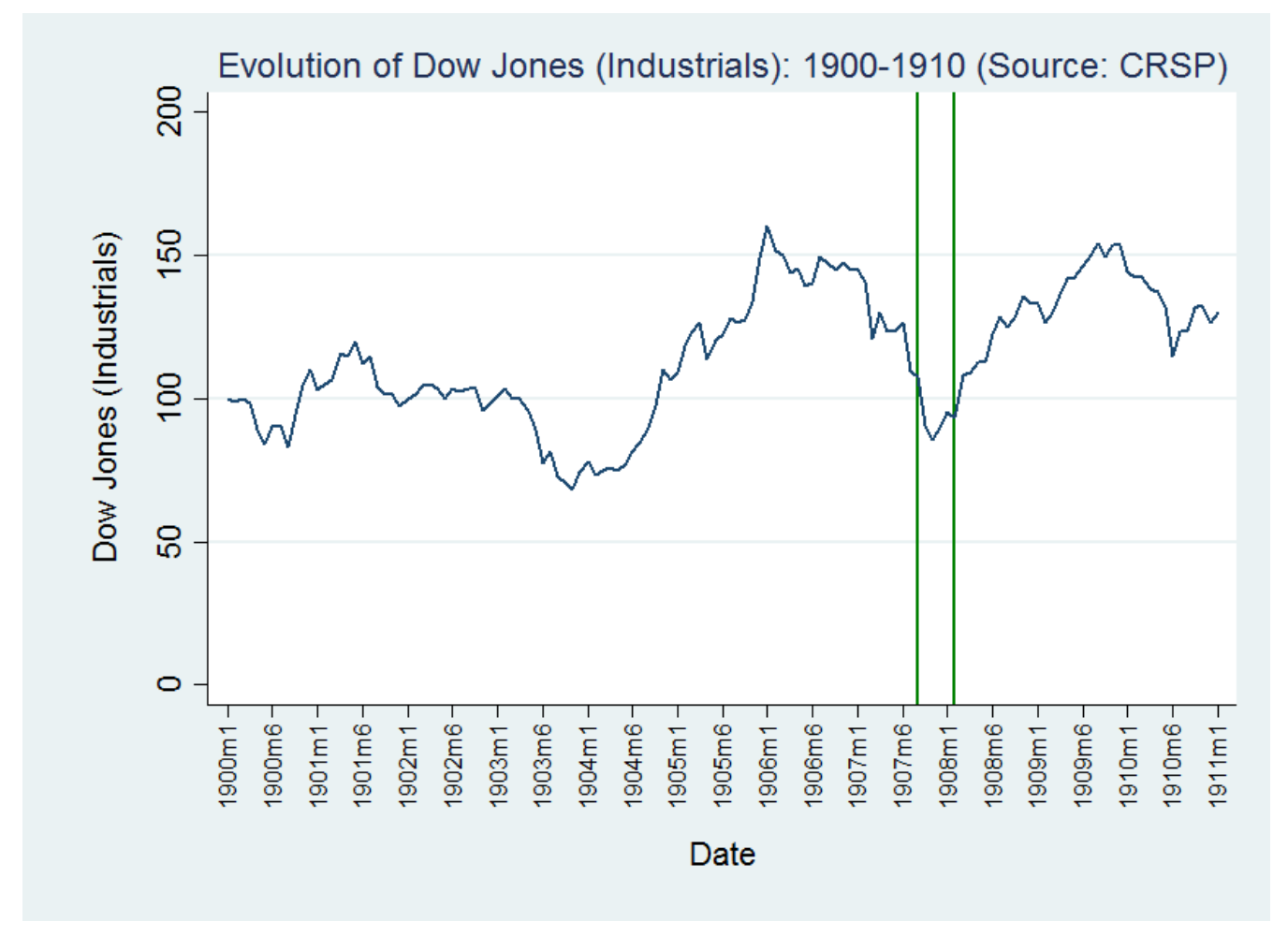

Figure 3: Evolution of Dow Jones Index: 1900-1910

These patterns of market indicators over the 1907 crisis and recovery look a lot like a modern-day market boom-bust cycle. U.S. financial markets had achieved a significant

\footnotetext{
${ }^{11}$ The contemporary/historical usage of "panic" is nowadays referred to as financial crisis.
} 


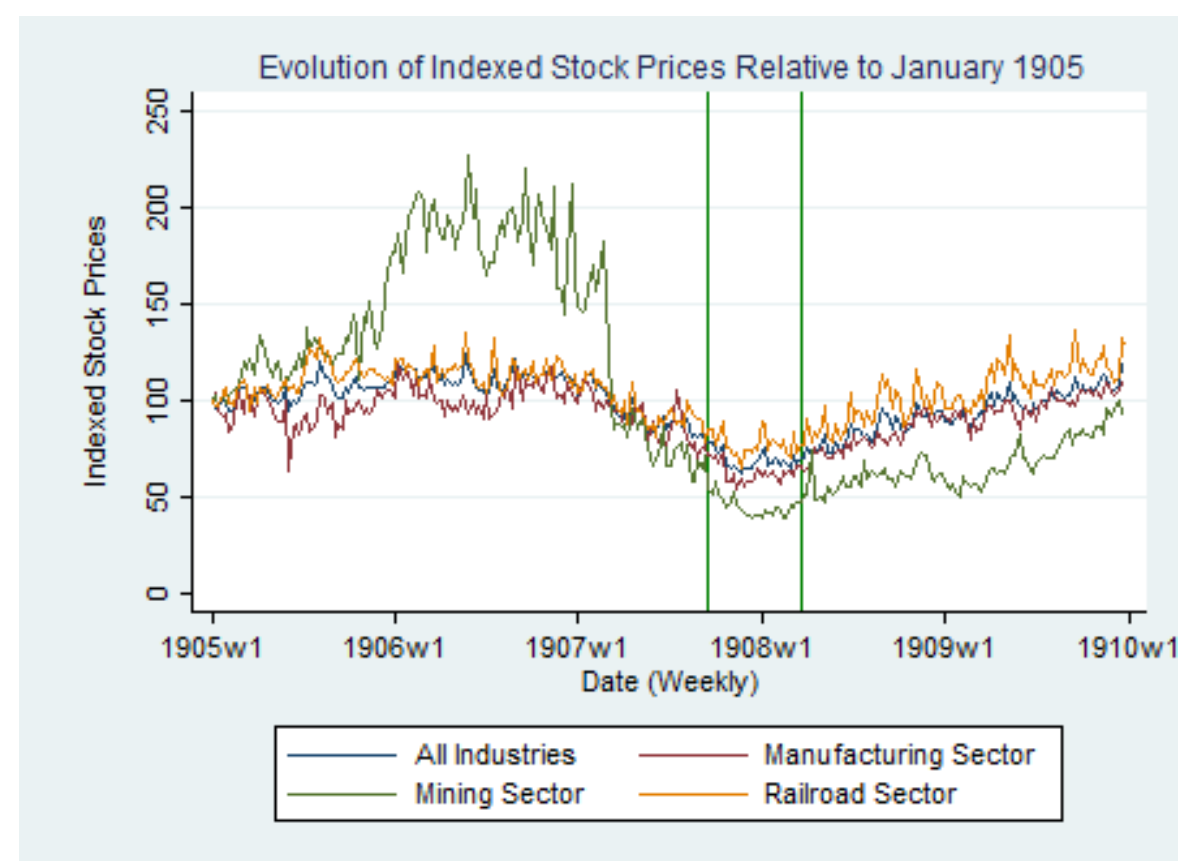

Figure 4: Daily Stock Prices Relative to January 1905

level of development and integration, both national and international. Stock exchanges and banks operated in all corners of the country (and the world), and the New York Stock Exchange had risen to dominance among the U.S. exchanges. Excess funds flowed into New York, by then the clear financial center of the United States, from all over the country and from England, France, Germany, and elsewhere around the world.

On October 16, 1907, the brokerage house of Otto Heinze was forced to close when the principal failed in his attempt to corner shares of the United Copper Company in order pull a classic short squeeze. The manipulations in United Copper shares caused wild swings in the stock's price, but the price ultimately plummeted and left Otto in financial ruin.

Heinze's failure was only the beginning of the story. United Copper was partly owned by Otto's brother, the notorious copper magnate, F.A. (Augustus) Heinze. ${ }^{12}$ The O. Heinze failure set off rumors that certain financial institutions had financed the failed short squeeze and therefore held unpayable debts from Otto Heinze. But Augustus was the key link in the rumor chain, as he had just a few months prior moved to Manhattan and taken an active interest in banking and finance - including Presidency of the Mer-

\footnotetext{
${ }^{12}$ For extensive details, see the Smithsonian Magazine article from September 2012 and Chapter 6 of Parker and Whaples (2013).
} 


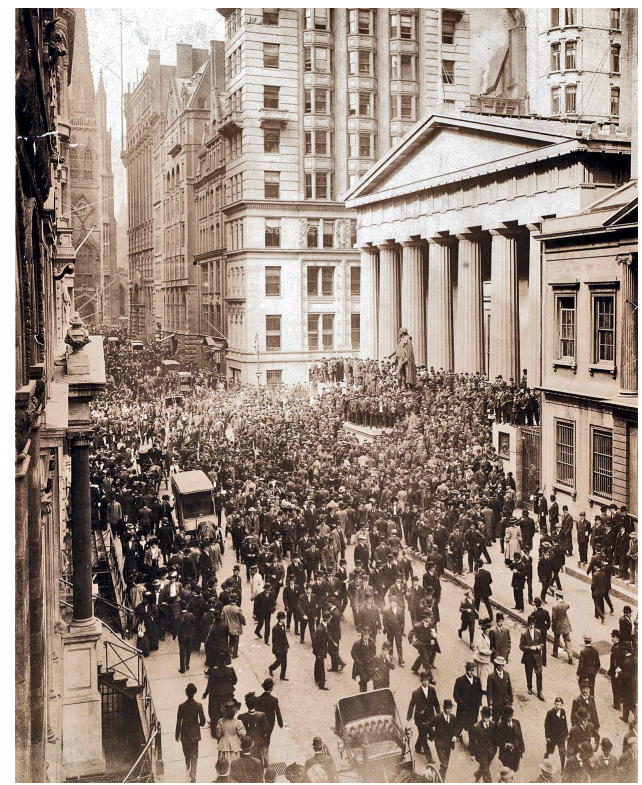

Figure 5: Price discovery process during the Panic of 1907

cantile Bank and directorships at several other banks and trust companies. ${ }^{13}$ Thus, as rumors spread about counterparties to Otto's brokerage firm, depositors ran on Mercantile National and on the trust companies with known ties to Heinze; first and foremost, the Knickerbocker Trust Company with $\$ 69$ million in assets (Tallman and Moen (1990)). After the closure of Knickerbocker Trust Company on Tuesday, October 22 ${ }^{\text {nd }}$, depositors rapidly began withdrawals from other trust companies. ${ }^{14}$ As banks faced withdrawals, money became scarce, and rates on short-term loans spiked; thereby causing difficulties in financing stock market transactions. Falling stock prices set off margin calls and further sell-off in stocks to cover.

In an era in which investors learned price information by traveling to or phoning their brokers - who, in turn, relied on a stream of information printed onto ticker tape arriving via telegraph - the only way to learn news in real time was to appear in person. The now famous photograph in Harper's Weekly during the panic, gives an impression of what that "price discovery" process looked like (see Figure 5 from Harper's Weekly).

The extensive reporting in the Commercial and Financial Chronicle of the time as well as contemporary economists and numerous subsequent researchers point out that rumors

\footnotetext{
${ }^{13}$ See the detailed reporting in the Commercial and Financial Chronicle in the weeks during and following the panic.

${ }^{14}$ Again, see the extensive details reported in the Commercial and Financial Chronicle as well as other contemporary financial press.
} 
- and the inability of investors to access and assess information - led to escalation into panic. ${ }^{15}$ Market participants could observe the runs on trusts and banks that had close ties to the Heinze brothers, and they could learn - with some lag - about stock price declines, but they had no way of accurately evaluating in real time the fundamental values of either the financial institutions or the corporations whose stocks served as collateral on millions of dollars' worth of loans.

The crisis narrative of O.M.W. Sprague (Sprague (1910), page 246), an eminent economist of the time, clearly indicates that contemporaries well understood the importance of information and uncertainty, and how those problems led to a crisis of confidence, panic, and runs on banks and the stock market. Here, a brief excerpt from his extensive coverage:

"After the August decline on the stock exchange a number of unfavorable events served to weaken confidence. The most important of these were the disclosures regarding the affairs of the New York street railway companies, which culminated in the appointment of receivers toward the end of September. There is, however, no evidence that distrust of the solvency of the banks either in New York or elsewhere had been excited. During the crisis distrust rapidly developed, but this was owing to causes similar to those which had produced the same effect in other crises and can be naturally accounted for by the events which marked its beginning.

The initial episode of the crisis was, as has often happened in previous instances, insignificant enough. Copper was, as we have seen, the one branch of industry in which a positive decline had taken place. No time could possibly have been chosen so unfavorable for venturesome attempts at manipulation either of copper itself or of the shares of copper companies. It happened that the particular disaster which precipitated the crisis was a copper gamble, the outcome of which would ordinarily have had no public importance."

Sprague also emphasized the lack of lender of last resort facility for the "shadow banks" of the day, the trust companies, and the antagonistic relationship between these uncharteredand loosely regulated-trust companies and the more tightly regulated commercial banks.

\footnotetext{
${ }^{15}$ See Sprague (1908) and Sprague (1910) as well as the modern analyses of Frydman et al. (2012), Gorton (1988), Calomiris and Gorton (1991), and Moen and Tallman (1992).
} 
In particular, the required reserve ratios of national banks exceeded the reserves typically held by trusts, and that gap led to a competitive advantage for the trusts and an arguably self-defeating unwillingness to assist trusts in the face of the 1907 liquidity freeze. In this pre-Fed era, the Clearing House Association of New York, a private clearing house, acted as an emergency lender to its members in crisis times. The trusts were not part of this club (Tallman and Moen (2014)). Moen and Tallman (1992) point out that loans at trust companies contracted by 37\% between August 22 and December 19, 1907. Loans at banks contracted by $19 \%$ during that same period.

The panic might have deepened if not for the rescue measures implemented in short order: The Treasury Department's $\$ 25$ million deposit in New York banks, followed on October $24^{\text {th }}$ by J. P. Morgan's now-famous bailout plan involving large sums of his own money and that of the city's top bankers. On October $26^{\text {th }}$, the New York Clearing House Association issued Clearing House loan certificates for its member banks (Tallman and Moen (1990) and Tallman and Moen (2012)). To further calm the markets, the treasury issued its own certificates on November $19^{\text {th }}$ and $20^{\text {th }}$. Notably, as Rodgers and Payne (2012) find and as is described in Kindleberger and Aliber (2011), the announcement by the Bank of France that it would discount American commercial paper for gold Eagles held in the Bank's reserves ultimately seemed to have stopped the downward spiral of equity prices. According to Rodgers and Payne (2012), the Bank of France repeated its announcement between November 22 and December 7, 1907. The authors also conclude that the Bank of France actions signaled an ongoing ability to provide liquidity, and thereby a more enduring resolution of the crisis, in contrast to Courtelyou's and Morgan's temporary injections of funds.

Wilson and Rodgers (2011) point out that, in addition to the various policy responses, the structure of the U.S. capital markets proved to be beneficial for the economy during the Panic of 1907. For example, the payment system for bond transactions was not necessarily tied to banks. Hence, investors could continue to receive payments even with banks in trouble. Additionally, most bond indentures stipulated that coupon and principal payments had to be made in gold, which further explains why the Bank of France announcements proved so helpful in stabilizing the market.

This downturn displayed characteristics also observed in earlier financial crises (Moen and Tallman (1992)): interest rates increased, stock prices decreased sharply, output in the real economy fell significantly, and financial institutions suffered from deposit withdrawals (see Gorton (1988) and Kindleberger and Aliber (2011)). The resulting contraction of 
loans yielded significant negative consequences for the real sector (see Moen and Tallman (1992) and Bruner and Carr (2008)).

\subsection{Stock market liquidity during the crisis}

Stock market liquidity measures, such as relative spreads and trading volume, highlight the progression of the crisis, transition to outright panic, and long duration of the recovery in the market: relative spreads started rising around March 1907, while trading volume dropped significantly (Figure 6). These trends accelerated in October 1907. While prices rebounded before the end of the year, spreads remained elevated and trading volume remained depressed and more variable until the following spring.

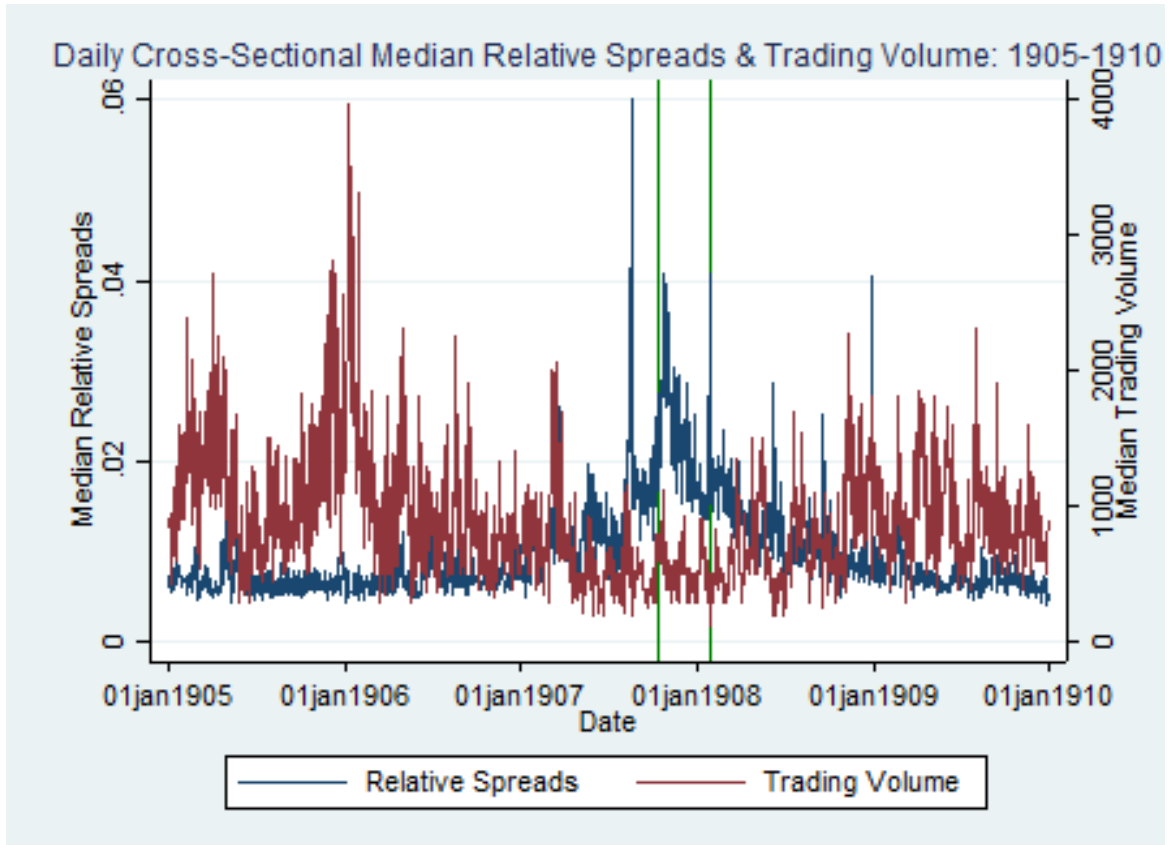

Figure 6: Median of Relative Spreads \& Trading Volume: 1905-1910

To more explicitly evaluate the changes in stock market illiquidty during the crisis, we estimate quantile regressions of daily relative bid-ask spreads for all common stocks trading on the NYSE from 1905 through 1909. We control for the price level and contemporaneous volatility, and then add binary indicator variables for the height of the panic (October 22nd - November 9th) and the rest of the financial crisis period outside of the peak (September 30 - October 21 and November 10 to January 31, 1908), as follows: ${ }^{16}$

\footnotetext{
${ }^{16}$ Since we have daily data, we proxy volatility with a "quasi-volatility" measure: each day's high
} 


$$
\left.\begin{array}{l}
\text { Relative Spreads }_{i, t, 25 \text { thquantile }} \\
\text { Relative Spreads }_{i, t, 5 \text { thquantile }} \\
\text { Relative Spreads }_{i, t, 75 \text { thquantile }}
\end{array}\right\} \begin{gathered}
=\beta_{0}+\beta_{1} \text { PanicHeight }_{t}+\beta_{2} \text { Crisis }_{t}+ \\
\beta_{3} \text { StockPrice }_{i, t}+\beta_{4} \text { QuasiVolatility }_{i, t}+\epsilon_{i, t}
\end{gathered}
$$

The analyses confirms and expands on the graphical evidence that relative spreads increase significantly, in both economic and statistical terms, during the crisis and especially so during the height of the Panic (Table 3). Indeed, the height of the panic effect is more than twice the effect of the crisis days just before and after the peak. The pattern holds across all three quartile estimations, with substantially increasing impact for higher spread quartiles. For both the height of the panic and for the surrounding crisis days, the median effect is more than two and a half times that for the lowest (most liquid) quartile, while the third quartile (least liquid) effect is well over six times that of the lowest quartile.

Volatility and stock prices follow the expected positive and negative patterns, respectively, and those estimated effects increase with each quartile of relative spreads. Notably, since the regression analysis controls for the two main drivers of spreads, stock price and asset valuation uncertainty (quasi-volatility), the crisis and panic indicators measure an additional effect, above and beyond the standard microstructure effects. In other words, these results indicate that additional panic-specific factors exacerbated the rising illiquidity in the stock market. In the following sections, we will dig a bit deeper to try to identify the role of funding illiquidity and then of incomplete information in driving up spreads.

\section{Market Liquidity and Funding Liquidity during the Panic}

The narrative of the Panic of 1907 points out the already fragile state of financial markets in the several months prior to the crisis, and general economic conditions had also weakened over the previous year. Odell and Weidenmier (2004) argue that the financial repercussions of the San Francisco earthquake in April of 1906 led to monetary stringency and made financial markets susceptible to a crisis. In the absence of a central bank, the setting of short-term borrowing rates was performed by the overnight call money market throughout our period of study. Funding liquidity issues therefore appear in the form of

minus low transaction price, divided by the last price of the day. We exclude observations for which quasi-volatility is equal to zero, since these observations likely indicate that the stock traded only once in that day, suggesting low liquidity and therefore higher spreads. 
elevated call loan rates.

As Brunnermeier and Pedersen (2009) establish in a theoretical framework, in periods of crisis positive feedback effects between funding illiquidity and market illiquidity might amplify each other. In such situations, decreasing availability of funds increase margin requirements and haircuts on collateral, inducing fire-sales of the underlying assets and a widening of bid-ask spreads, reflecting higher inventory holding costs for market makers. As market liquidity dries up, margin calls and haircuts increase and reduce funding liquidity even further.

This mutually enhancing feedback between funding illiquidity and market illiquidity is particularly important in opaque markets with asymmetric information about assets' true valuations. If information is symmetric, margins and haircuts tend to be stabilizing towards a new equilibrium. Under asymmetric information, though, we expect increased correlation between funding illiquidity and market illiquidity, as well as an increase in commonality between asset returns, volatility and effective spreads - likely compounded by investors' flight to quality.

Li and Ma (2016) provide an explicit model of the feedback effect from funding illiquidity to market illiquidity for the case of banks, which typically offer a prime example of opaque balance sheets. Their model provides a nice theoretical foundation for the 1907 Panic, which was triggered by a run on Knickerbocker Trust and subsequently on other trusts and banks as well. ${ }^{17}$

Since we cannot observe the margins and haircuts set by the exchanges during our period, we can only indirectly test this relationship between funding illiquidity and market illiquidity. Taking daily maximum call money rates as our measure of funding illiquidity and spreads as the measure of market illiquidity, Figure 7 suggests that the co-movement between daily maximum call money rates and relative spreads increased dramatically at the peak of the Panic in October 1907. The same is true for the daily minimum call money rates, as depicted by Figure 7. In other words, our measure of funding illiquidity seems to be highly correlated with market illiquidity during these hectic two weeks. Afterwards as before - we see a decoupling of funding liquidity and market liquidity and a convergence of market illiquidity to more normal levels despite the fact that funding illiquidity spikes toward the end of 1907.

\footnotetext{
${ }^{17}$ The trusts in the early twentieth century played a role similar to shadow banks about a hundred years later.
} 

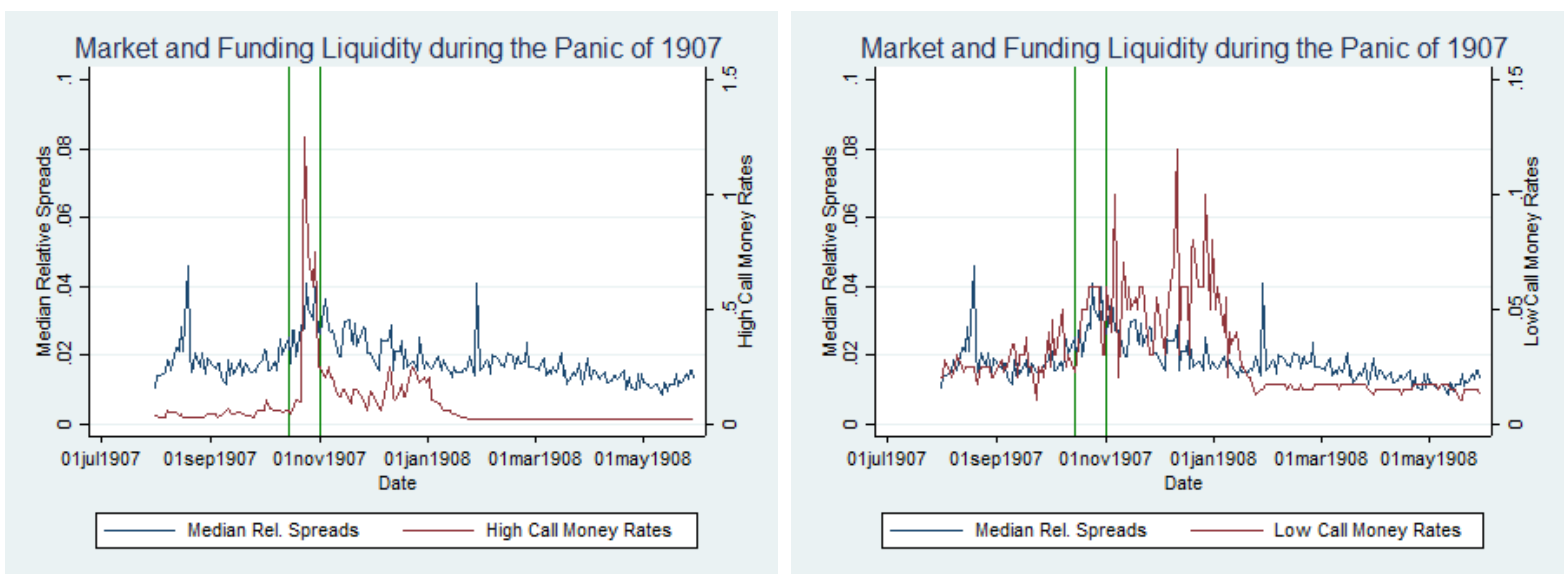

\section{Figure 7: Market and Funding Illiquidity during the Panic of 1907: High and Low Call Money Rates vs. Relative Spreads}

To confirm this hypothesis, we compute correlations between call money rates and relative spreads and then analyze the relationship in a more complete model of spreads. We find that the correlation peaks between October 22 and November 9, $1907 .^{18}$ To be more precise, the correlation between call money rates and relative spreads reaches a maximum of 0.63 for the period from October 22 (Tuesday) - November 9 (Tuesday), 1907. ${ }^{19}$ This is strong evidence that funding liquidity was a major driver of market liquidity particularly during the crisis.

To add further robustness to the correlation and graphical analyses, we re-estimate the model from Section 3, augmented by daily maximum call loan rates. As in Section 3, the independent variables include daily stock prices, daily quasi-volatility, and the same crisis/panic indicator variables. ${ }^{20}$

\footnotetext{
${ }^{18}$ In other periods these correlations tend to be weakly positive.

${ }^{19}$ These correlations relate to the maximum of the call money rates reported. In midst of the turmoil at October $23^{\text {th }}$ the highest of the quoted funding rates reached a level of 125 percent, significantly up from neighboring days. When using the minimum of the call money rates, we find that rates stay at six percent throughout the the turmoil. Nevertheless correlation between minimum call money rates and spreads also peaked during this period with a correlation coefficient of about 30 percent. Figure 8 provides a graphical illustration of how median relative spreads and call money rates evolved during this period. The light red color indicates rates and spreads above two percent; the dark red color indicates rates above four percent. This "heatmap" shows how interlinked spreads and call money rates were during the panic.

${ }^{20}$ Note that, as before, we exclude observations for which quasi-volatility is equal to zero, due to the likelihood that such instances indicate a single trade for that day. The height of the panic is October 22 - November 9, 1907 and the rest of the crisis, outside the peak, is September 30 - October 21 and November 10 to January 31, 1908.
} 


\begin{tabular}{|c|c|c|c|}
\hline Date & Median Rel Spread & Low Call Money Rate & High Call Money Rate \\
\hline 30. Sep 07 & 0.0200401 & 0.04 & 0.06 \\
\hline 01. Oct 07 & 0.0201621 & 0.025 & 0.06 \\
\hline 02. Oct 07 & 0.0197277 & 0.045 & 0.1 \\
\hline 03. Oct 07 & 0.0134496 & 0.03 & 0.085 \\
\hline 04. Oct 07 & 0.0153992 & 0.03 & 0.065 \\
\hline 05. Oct 07 & 0.0124077 & & \\
\hline 07. Oct 07 & 0.0186916 & 0.045 & 0.06 \\
\hline 08. Oct 07 & 0.0148148 & 0.05 & 0.06 \\
\hline 09. Oct 07 & 0.0172414 & 0.03 & 0.06 \\
\hline 10. Oct 07 & 0.025 & 0.025 & 0.06 \\
\hline 11. Oct 07 & 0.0194175 & 0.03 & 0.05 \\
\hline 12. Oct 07 & 0.0169504 & & \\
\hline 14. Oct 07 & 0.0274178 & 0.0225 & 0.06 \\
\hline 15. Oct 07 & 0.0172414 & 0.0275 & 0.04 \\
\hline 16. Oct 07 & 0.0244898 & 0.035 & 0.06 \\
\hline 17. Oct 07 & 0.0273973 & 0.04 & 0.07 \\
\hline 18. Oct 07 & 0.0176991 & 0.05 & 0.1 \\
\hline 19. Oct 07 & 0.0254242 & & \\
\hline 21. Oct 07 & 0.0251582 & 0.05 & 0.0925 \\
\hline 22. Oct 07 & 0.0289855 & 0.06 & 0.7 \\
\hline 23. Oct 07 & 0.0266667 & 0.06 & 1.25 \\
\hline 24. Oct 07 & 0.0408163 & 0.06 & 1 \\
\hline 25. Oct 07 & 0.034617 & 0.06 & 0.75 \\
\hline 26. Oct 07 & 0.0211416 & & \\
\hline 28. Oct 07 & 0.0301538 & 0.06 & 0.6 \\
\hline 29. Oct 07 & 0.030303 & 0.04 & 0.75 \\
\hline 30. Oct 07 & 0.0327869 & 0.03 & 0.5 \\
\hline 31. Oct 07 & 0.0256452 & 0.03 & 0.25 \\
\hline 01. Nov 07 & 0.0253165 & 0.06 & 0.25 \\
\hline 02. Nov 07 & 0.039368 & & \\
\hline 04. Nov 07 & 0.0337345 & & \\
\hline 06. Nov 07 & 0.027027 & 0.1 & 0.25 \\
\hline 07. Nov 07 & 0.0258625 & 0.06 & 0.2 \\
\hline 08. Nov 07 & 0.0266667 & 0.02 & 0.2 \\
\hline 09. Nov 07 & 0.0266667 & & \\
\hline 11. Nov 07 & 0.0216607 & 0.07 & 0.13 \\
\hline 12. Nov 07 & 0.020202 & 0.06 & 0.12 \\
\hline 13. Nov 07 & 0.019802 & 0.05 & 0.12 \\
\hline 14. Nov 07 & 0.0229885 & 0.06 & 0.15 \\
\hline 15. Nov 07 & 0.0285773 & 0.05 & 0.15 \\
\hline 16. Nov 07 & 0.0181594 & & \\
\hline 18. Nov 07 & 0.0307765 & 0.055 & 0.1 \\
\hline 19. Nov 07 & 0.0188877 & 0.05 & 0.09 \\
\hline 20. Nov 07 & 0.0210526 & 0.06 & 0.15 \\
\hline 21. Nov 07 & 0.0289855 & 0.06 & 0.15 \\
\hline 22. Nov 07 & 0.0210873 & 0.06 & 0.15 \\
\hline 23. Nov 07 & 0.0168067 & & \\
\hline 25. Nov 07 & 0.0278063 & 0.03 & 0.1 \\
\hline 26. Nov 07 & 0.0273973 & 0.03 & 0.08 \\
\hline 27. Nov 07 & 0.0194175 & & \\
\hline 29. Nov 07 & 0.0207096 & 0.055 & 0.14 \\
\hline 30. Nov 07 & 0.01787 & & \\
\hline 02. Dec 07 & 0.0214797 & 0.0005 & 0.0013 \\
\hline 03. Dec 07 & 0.0215054 & 0.0004 & 0.0008 \\
\hline 04. Dec 07 & 0.0168067 & 0.03 & 0.07 \\
\hline 05. Dec 07 & 0.0226394 & 0.045 & 0.06 \\
\hline 06. Dec 07 & 0.0210526 & 0.055 & 0.09 \\
\hline 07. Dec 07 & 0.0195448 & & \\
\hline 09. Dec 07 & 0.0240964 & 0.07 & 0.2 \\
\hline 10. Dec 07 & 0.0239286 & 0.1 & 0.25 \\
\hline 11. Dec 07 & 0.0267427 & 0.12 & 0.22 \\
\hline 12. Dec 07 & 0.015444 & 0.03 & 0.12 \\
\hline 13. Dec 07 & 0.0208927 & 0.06 & 0.1 \\
\hline 14. Dec 07 & 0.0131525 & & \\
\hline 16. Dec 07 & 0.0240999 & 0.06 & 0.14 \\
\hline 17. Dec 07 & 0.0237154 & 0.06 & 0.17 \\
\hline 18. Dec 07 & 0.0159222 & 0.03 & 0.12 \\
\hline 19. Dec 07 & 0.0197542 & 0.075 & 0.12 \\
\hline 20. Dec 07 & 0.0162602 & 0.08 & 0.16 \\
\hline 21. Dec 07 & 0.0143062 & & \\
\hline 22. Dec 07 & 0.018018 & 0.06 & 0.25 \\
\hline 24. Dec 07 & 0.017094 & & \\
\hline 26. Dec 07 & 0.016129 & 0.06 & 0.2 \\
\hline 27. Dec 07 & 0.020202 & 0.1 & 0.18 \\
\hline 28. Dec 07 & 0.0143715 & & \\
\hline 30. Dec 07 & 0.0155039 & 0.05 & 0.2 \\
\hline 31. Dec 07 & 0.0162308 & & \\
\hline 02. Jan 08 & 0.0136054 & 0.05 & 0.2 \\
\hline 03. Jan 08 & 0.0152906 & 0.06 & 0.1 \\
\hline 04. Jan 08 & 0.015748 & & \\
\hline 06. Jan 08 & 0.018018 & 0.04 & 0.09 \\
\hline 07. Jan 08 & 0.0165289 & 0.055 & 0.09 \\
\hline 08. Jan 08 & 0.0149878 & 0.02 & 0.07 \\
\hline 09. Jan 08 & 0.019802 & 0.04 & 0.055 \\
\hline 10. Jan 08 & 0.015873 & 0.035 & 0.055 \\
\hline
\end{tabular}

Figure 8: Relative Spreads \& Call Money Rates: Sep 30, 1907 - Jan 10, 1908 


$$
\left.\begin{array}{l}
\text { Relative Spreads }_{i, t, 25 \text { thquantile }} \\
\text { Relative Spreads }_{i, t, 50 \text { thquantile }} \\
\text { Relative Spreads }_{i, t, 75 \text { thquantile }}
\end{array}\right\} \begin{gathered}
=a_{i}+\beta_{1} \text { HeightofPanic } \text { S }_{t}+\beta_{2} \text { Crisis }_{t}+ \\
\beta_{3} \text { HighCallMoneyRates } \\
+
\end{gathered}
$$

Note that despite the time subscript "t" on all variables, the call money rates actually precede the closing relative spread. The quotation of call money rates took place throughout the trading day, but banks typically set rates before noon, particularly for renewals (many of these loans were rolled over for several days, but the borrower had to pay each new day's renewal rate and therefore had to take the risk of a higher rate as the market fluctuated). So, the bid and ask quotes at the close of the market would have taken into account the call money rates that had prevailed that day. In the quantile regressions we therefore use intra-day maximum call money rates to capture the leading role of funding liquidity.

In line with the prior results, call money rates lead relative spreads for the most illiquid stocks only, those in the 75 th percentile of relative spreads (Table 4). We find that the correlation between funding liquidity (as measured by call money rates) and market liquidity (as measured by spreads) increases as stocks become more illiquid; there is no significant effect for the most liquid or median liquid stocks. The Panic itself had strongly positive effects on relative spreads, both during the height of the panic as well as during the remainder of the panic. Spreads are significantly higher for all quartiles of stocks. The most liquid stocks see an increase in relative spreads of about 0.3 percent, whereas the most illiquid stocks experience an increase in spreads of about 0.9 percent during the height of the crisis. This effect reflects strong simultaneous feedback effects between market and funding illiquidity across the illiquidity spectrum. There is an extra effect from 0 (lowest quartile) of up to .4 percent (in the highest quartile) for the remainder of the crisis. It is also important to highlight that, as theory predicts, asset valuation uncertainty (quasi-volatility) is consistently strong and positively related to relative spreads, and stock prices relate negatively and statistically significantly. The panic indicator variables and the maximum call money rates are therefore providing additional explanatory power, over and above the generally higher volatility and lower prices of the time. ${ }^{21}$

\footnotetext{
${ }^{21}$ These results are robust across different specifications of call money rates. As depicted by Table 8 , the results also hold when the daily minimum call money rates are used instead of the maximum rates.
} 


\section{$5 \quad$ Illiquidity as a Factor in Asset Pricing}

Next we investigate the impact of illiquidity in a general equilibrium market context. In particular, we investigate whether illiquidity was priced by the market, as suggested by Holmström and Tirole (2001), Pástor and Stambaugh (2003), or Acharya and Pedersen (2005). In this tradition we augment a standard Fama-French three factor model with a liquidity factor, measured by relative bid-ask spreads. ${ }^{22}$

In order to test this model, we first construct size and book-to-market factors using the procedure in Fama and French (1992). ${ }^{23}$ We define Book-to-market as:

$$
\text { Book-to-Market }(\mathrm{B} / \mathrm{M})=\frac{\text { Total book value of common stock }}{\text { Number of common shares outstanding } * \text { Stock Price }}
$$

We then break our entire sample of stocks into three book-to-market equity groups based on the breakpoints for the bottom 30\% (Growth), middle $40 \%$ (Neutral), and top 30\% (Value) of the ranked values of the book-to-market ratio. ${ }^{24}$ We furthermore sort our sample of stocks into size portfolios based on market equity. Market equity (common stock) in our case is defined as:

$$
\text { Market value of common equity }=\left(\frac{\text { Total common equity stock }}{\text { Par value of common }}\right) * \text { Stock Price }
$$

We split the sample into two equal groups, small and big, based on the median value of market capitalization. These sorts follows Fama and French (1992) as well as Fama and French (1993). The Fama/French factors are constructed using the six value-weighted portfolios formed on size and book-to-market. SMB (Small minus Big) is the average return on the three small portfolios minus the average return on the three big portfolios:

$\mathrm{SMB}=\frac{1}{3}($ Small Value + Small Neutral + Small Growth $)-\frac{1}{3}($ Big Value + Big Neutral + Big Growth $)$

HML (High Minus Low) is the average return on the two value portfolios minus the average return on the two growth portfolios:

\footnotetext{
${ }^{22}$ We also run regressions with alternative illiquidity measures such as the Amihud illiquidity measure and volume but while qualitatively and quantitatively similar, the results appear somewhat less statistically significant.

${ }^{23}$ Kenneth French's online database starts much later.

${ }^{24}$ Note that for this section stocks trading in the Unlisted department of the NYSE had to be excluded due to the lack of capital stock data for this type of stocks.
} 


$$
\mathrm{HML}=\frac{1}{2}(\text { Small Value }+ \text { Big Value })-\frac{1}{2}(\text { Small Growth }+ \text { Big Growth })
$$

Since short T-bills did not yet exist during the period of our study, we define the excess return $R^{m}-R^{0}$ relative to a zero-beta portfolio, using the gold flow rate (i.e., growth rate in the gold stock of the U.S. government). We choose to use gold flow rates for two reasons. First of all, this rate represents the zero-beta portfolio as it correlates with the market return at only $-0.01 .^{25}$ Secondly, it seems that gold reserves were viewed as a safe haven by investors: As described by Rodgers and Payne (2012), the Panic lost some of its steam once the level of gold stock reserves rose towards 1908.

Once we have our size and market-to-book factors, we follow the traditional two-step OLS methodology of Fama and MacBeth (1973) to estimate portfolio betas and factor prices. ${ }^{26}$ In the first stage we estimate firm-specific in-sample regression coefficients ("Betas") for the three Fama-French factors plus the illiquidity measure. In this regression, $R_{i, t}$ is the firm-specific time-varying monthly return, where i denotes the companies and $\mathrm{t}$ is a timeindex (monthly). ${ }^{27} R_{t}^{m}-R_{t}^{0}$ denotes the excess market return and "Spread" denotes our measure for illiquidity, which is relative bid-ask spreads. We estimate the first stage as follows:

$$
R_{i, t}-R_{t}^{0}=\beta_{1, i} *\left(R_{t}^{m}-R_{t}^{0}\right)+\beta_{2, i} * \operatorname{Spread}_{i, t}+\beta_{3, i} S M B+\beta_{4, i} H M L+\epsilon_{i, t}
$$

In the second stage, we regress the cross-section of average monthly expected returns on the estimated factor sensitivities of the first stage. The estimated parameters of the second stage can be interpreted as the associated market prices of the corresponding risk factors. If the model is well specified $\lambda_{0}$ should not be statistically significant.

$$
E\left[R_{i}-R^{0}\right]=\lambda_{0}+\lambda_{1} \widehat{\beta_{1, i}}+\lambda_{2} \widehat{\beta_{2, i}}+\lambda_{3} \widehat{\beta_{3, i}}+\lambda_{4} \widehat{\beta_{4, i}}+\eta_{i}
$$

The results of our asset pricing analysis (Table 5) indicate that liquidity risk, as measured by the relative bid-ask spread, is priced positively at roughly 112 basis points. Thus, investors expected and earned a liquidity premium very much in the same order of magnitude as in markets a century later. The market risk premium in our sample is negligible. Moreover, in line with Chabot et al. (2014) we find negative contributions of the SMB and HML factors. In the case of firm size, the associated risk around the

\footnotetext{
${ }^{25}$ The market return is defined as the equally-weighted return of all stocks in our sample.

${ }^{26}$ See chapter 12 of Cochrane (2005) for example.

${ }^{27}$ Note that returns are calculated excluding ex-dividend dates as detailed information on firm-specific dividends is missing. We drop 0.6 percent of the entire dataset by excluding ex-dividend dates.
} 
early 20th century differs considerably from more recent times, such that a number of the largest firms may well have posed higher stock return risk than smaller firms. Indeed, the largest corporations in that era - companies like U S Steel and the major railroad networks - were growing and integrating and, at the same time, faced repeated threats from antitrust actions and regulatory intervention. Thus, firm size as a growth proxy is most likely anachronistic in this context. Finally, an estimated alpha of zero suggests that all relevant factors for asset pricing have been identified.

\section{Information and Opacity as the Main Drivers of Market Illiquidity}

Thus far, we have assembled some of the key pieces of the 1907 picture: 1 . that stock market illiquidity (relative bid-ask spreads) rose dramatically during the crisis, especially during the height of the panic, and did so above and beyond the effects of rising volatility and falling prices; 2 . that funding illiquidity exacerbated market illiquidity during the peak weeks of the crisis; and 3. that moreover, market investors priced in such illiquidity risk. We now take the analysis even further and try to establish that the core of the illiquidity problem lay - as we hypothesize - in the opaqueness of information in the market.

We start by reviewing theoretical work concerning the relationship between opaqueness and price discovery. We then test the theory by decomposing bid-ask spreads into information and non-information components, following Huang and Stoll (1997).

\subsection{Opaqueness and Price Discovery}

At the start of the panic, rumors about the solvency of banks and trusts, notably Knickerbocker Trust, spread widely, as evidenced by repeated commentaries to this effect published in the New York Times and other contemporary newspapers. The effects were contained only after the liquidity infusions by Treasury Secretary Courtelyou, J.P. Morgan, and others, as well as the well-publicized examinations of the Mercantile by the New York Clearing House and the purging of the tainted Heinze interests there. The rumors of certain banks' involvement in the failed corner and potential insolvencies added to a general demoralization and uncertainty over economic conditions and the specific conditions in the mining sector, in particular. Despite public reassurances, fears about impending bank liquidations continued because of the general lack of information about financial institution balance sheets and the true state of their liquidity. Thus, opaqueness permitted rumors to reinforce the already declining market and tight money conditions. 
In this regard, Bernardo and Welch (2004) provide a theoretical framework which explains how rumor-based runs on financial markets can arise. In order to avoid the liquidation of shares at a bad "post-run" price, each investor may prefer to sell shares today at the "inrun" price. If many investors fear alike, this in itself will cause a run on financial markets. Bernardo and Welch (2004) conclude that liquidity runs and crises are not necessarily caused by liquidity shocks per se, but instead by the fear of future liquidity shocks. Such fears are more likely the more opaque the economic environment. He and Manela (2014) show the same effect in a different framework. They study dynamic rumor-based runs on financial institutions with endogenous information acquisition. Agents who are unsure about banks' liquidity worry that other agents, who might have received even worse signals, withdraw before them. Hence, in order to front-run those agents with even worse signals, they start the run on the financial institution themselves. The fear of being too late increases the incentives to run. Thus, He and Manela (2014) and Bernardo and Welch (2004) offer an appropriate rationale for the happenings in the autumn of 1907. If these arguments hold, we should observe increased adverse selection risk as well as increased trading volume right after the failure of Heinze's stock corner. Both increased adverse selection risk and increased selling pressure should in turn drive up bid-ask spreads, making trading more expensive and traders reluctant to do so. At the same time, these theories imply a moderation of the runs once the concerns of market participants can be credibly resolved by (coordinated) market interventions.

Hellwig and Zhang (2012) establish a time-varying role of information during a crisis. They demonstrate that in the absence of intervention, markets tend to be more liquid at the onset of a crisis than towards the end. Specifically, they argue that the strategies over information gathering may depend on the liquidity in a given market. Strategic information acquisition may change across agents due to changing assets liquidity and valuation uncertainty about future states of the world. A vicious cycle can evolve in reaction to an unexpected event (i.e., in this case the failure of a stock corner) that leads to increased informational risk, which in turn leads to higher spreads, which again reinforces the trader's view that informational risk has indeed increased, and therefore spreads increase even more. The spiraling information problem freezes liquidity in the market, such that we should observe increasing illiquidity over the course of the crisis (also pointed out by Donaldson (1992)) as well as constantly increasing adverse selection risk for the cross section of companies. The Hellwig-Zhang model implies that outside interventions can stop such spirals, especially when independent information is generated. 
To the extent that the interventions of J.P. Morgan, Secretary Courtelyou, and of the Clearing House reflected positive information about the solvency of the underlying firms (and the removal of Heinze interests at the Mercantile further committed to severing all ties to the failed Heinze brokerage house), it did reduce the need of market participants to produce costly information of their own. As described in Section 3, on October 24, 1907, J.P. Morgan - together with other wealthy individuals - pledged large sums of money in order to calm markets and restore confidence. With each new emergency to arise, trusted parties - the U.S. Treasury, the New York Clearing House, J.P. Morgan, and other eminent financiers and industrialists - jumped in to assess the soundness of each institution in question, reveal that information publicly, and then to provide a backstop to "good" institutions suffering only temporary illiquidity. We expect that these interventions contributed critically to ending the liquidity freeze. Successful interventions should be reflected in declining spreads, increasing trading volume, and a reduction in overall informational risk as well as valuation uncertainty.

The theory further suggests that stocks with the most opaque financial reporting practices and those most prone to manipulations - such as naked short sales, corners, and short squeezes - suffer the most severe adverse selection effects. In these regards, mining stocks ranked among the worst, and it was therefore no accident that an copper company trading on the Curb market became the target of an attempted corner and short squeeze in 1907. The company in question, the United Copper Company, was incorporated in 1902 by F. Augustus Heinze, the brother of Otto Heinze and a copper magnate who had fought for years - largely against the Amalgamated Copper - to gain access to lucrative copper mines in Butte, Montana. Otto Heinze also held stakes through United Copper Company in a number of other mining companies such as The Montana Ore Purchasing Company, The Nipper Consolidated Copper Company, The Minnie Healy Mining Company, The Corra Rock-Island Mining Company, and the The Belmont Mining Company. ${ }^{28}$

Furthermore, given the differing extent and thoroughness with which different industries published their accounting information (Archambault and Archambault (2005)), we conjecture that stocks in the more transparent sectors (e.g., utilities and railroad sector, which provided accounting information to the public in great detail) should exhibit lower informational risk than other sectors, such as manufacturing and mining, that published meager information on a sporadic basis. Transparency arguably mitigates potential for insider trading and adverse selection costs, assuming that insiders provide accurate information. ${ }^{29}$

\footnotetext{
${ }^{28}$ See New York Times Article from April 29, 1902 regarding United Copper Company.

${ }^{29}$ We do note that transparency may be illusory in this period, as companies rarely produced audited
} 
That information asymmetry and adverse selection risk might not only differ across industries, but also across certain types of stocks is suggested by Hellwig and Zhang (2012). The authors show in an OTC-market setting that information acquisition may differ across liquid and illiquid markets. Chang (2012) goes a step further and demonstrates how limited market participation can arise as a result of informational frictions and how it then leads to distinct notions of illiquidity. In her theoretical framework she analyzes two types of informational frictions: sellers' private information about the quality of their assets and their private information of what motivates them to trade (e.g., different needs for liquidity). Her model endogenously generates and identifies the effects that adverse selection risk might have on transaction costs and volumes. In this environment, the trader who wants to sell her asset quickly is either trying to get rid of a low-quality asset, or simply has an urgent need for cash. If the other side of the transaction, the buyer, cannot differentiate between the two motives for trading, adverse selection risk will increase. This phenomenon should arise especially for illiquid stocks, as they are traded less frequently and market participants have more difficulty determining the fundamental value of the stock. Hence, we expect to find that adverse selection risk differs significantly between liquid and illiquid stocks. Moreover, we expect to find that adverse selection risk increases even more during crisis times. In a highly uncertain period, those problems might be disproportionately greater than in non-crisis times.

One means of offsetting some of the opaqueness is vetting by a trusted organization. Listing on the NYSE brought with it this sort of certification of quality, based on the exchange's listing requirements, which involved disclosure and examination of financial statements. The NYSE also maintained an "unlisted department" to trade in stocks that 1. could not meet NYSE listing requirements or 2. chose not to disclose the information required for an application for an official listing. Hence, since the NYSE did not impose any disclosure rules on stocks trading in the Unlisted department, less public information was available about these stocks, and they presumably therefore faced greater susceptibility to information shocks and rumors than stocks of companies that published more information. Episodes of heightened uncertainty may exacerbate such information problems. Thus, we expect that unlisted stocks are particularly vulnerable in a panic.

\subsection{Decomposition of Bid-Ask Spreads}

In order to analyze these questions, we decompose spreads into their three main components information risk, inventory holding risk and order processing costs. Information accounts. 
risk - equivalently, adverse selection risk - captures the risk of market makers trading against better informed traders. Arrival of (fundamental) information implies a change in the mean of the value of the underlying security. Since market makers expect to lose money in trading with insiders, they protect themselves against losses by charging wider spreads. Inventory holding costs arise when risk averse market makers' exposures temporarily, due to some trade with clients, deviate from their optimal portfolio holdings. As they attempt to converge back to their desired portfolio holdings over time, they will alter bid and ask quotes to induce selling if their portfolios have grown too long or buying if they have fallen short of the desired levels. Accordingly, their price quotes will induce autocorrelation, which ultimately will be reflected in transactions prices and trades. Order processing costs are considered compensation for technical costs of order handling and settlement. Importantly, they cannot be observationally distinguished from rents due to market power. Accordingly, oligopoly rents are subsumed under operating costs. Operating costs are intimately related to the bid-ask wedge, i.e. the cost of a round-trip transaction in the (hypothetical) absence of the other two trading motives.

We estimate these three cost components using the Huang and Stoll (1997) spread decomposition, as refined by Gehrig and Haas (2015). In the framework of Huang and Stoll, order processing costs are identified by the variance of the bid-ask bounce, while inventory holding costs are identified by serial correlation of transactions prices and adverse selection costs are identified by changing means of relative bid-ask spreads. The refinement of Gehrig and Haas insures that the three different cost components of the quoted bid-ask spread add up to one.

In the model of Huang and Stoll (1997), the time frame consists of three separate and sequential events. Stock i's fundamental value, $V_{i, t}$, is unobservable on day t. The bid and ask quotes are set right after the fundamental stock value has been determined. $M_{i, t}$ denotes the quote midpoint and is calculated from the quotes that were posted by a market maker just before a transaction happened. $P_{i, t}$ denotes the respective transaction price. $Q_{i, t}$ denotes a trade direction indicator variable. It takes the value of 1 if the transaction price exceeds the midquote (i.e., if a transaction is buyer-initiated), and it takes the value of -1 if the transaction price is smaller than the midquote (i.e., if a transaction is seller-initiated). It equals zero if the transaction price is equal to the midquote. ${ }^{30}$

\footnotetext{
${ }^{30}$ Note that for historical data the last transaction price of a given trading day does not necessarily refer to a transaction price being quoted at the end of that trading day (i.e., at 4:30pm). It could very well be the case that for very infrequently traded stocks, the last transaction price occurred well before 4:30pm.
} 
Subsequent transactions and their respective transaction volumes are assumed to be serially correlated. The conditional expectation of the trade indicator variable $Q_{t}$ at time $t-1$ given $Q_{t-2}$ is, therefore, shown to be:

$$
E\left(Q_{i, t-1} \mid Q_{i, t-2}\right)=\left(1-2 \pi_{i, t}\right) Q_{i, t-2}
$$

where $\pi_{i, t}$ denotes the probability that the current trade is of opposite sign to the previous trade.

Huang and Stoll (1997) estimate equation 9 simultaneously with equation 10 in order to estimate the different cost components of the spread. In equation 10, $S_{i, t}$ denotes the equity bid-ask spread and $\alpha_{i, t}$ denotes the percentage of the spread that is associated with informational cost (i.e., adverse selection cost). From this equation it becomes obvious how adverse selection costs are measured, as $\alpha_{i, t}$ is the coefficient of the difference between what the actual trade turned out to be (i.e., $\frac{S_{i, t-1}}{2} Q_{i, t-1}$ ) and what a market participant expected the trade to be based on the previous trade (i.e., $\frac{S_{i, t-2}}{2} \mathbb{E}\left[Q_{i, t-1} \mid Q_{i, t-2}\right]$ ). Hence, $\alpha_{i, t}$, or informational costs, only arise if the current trade brings about a surprise relative to the previous trade. $\beta_{i, t}$, the percentage of the spread that is associated with inventory cost, is only measured with respect to the current trade and denotes the changes in the market maker's inventory holdings that she later might need to adjust. $\epsilon_{i, t}$ refers to a public information shock and is assumed to be serially uncorrelated.

$$
\Delta M_{i, t}=\left(\alpha_{i, t}+\beta_{i, t}\right) \frac{S_{i, t-1}}{2} Q_{i, t-1}-\alpha_{i, t} \frac{S_{i, t-2}}{2}\left(1-2 \pi_{i, t}\right) Q_{i, t-2}+\epsilon_{i, t} .
$$

We estimate the parameters of equation 9 and $10, \alpha_{i, t}, \beta_{i, t}$, and $\pi_{i, t}$, using the generalized method of moments (GMM) procedure of Hansen and Singleton (1982) and Hansen (1982). The optimal weighting matrix is constructed using the method proposed in Wooldridge (2002). Under this procedure, the parameter estimates have to be chosen such that they minimize:

$$
Q_{N}(\theta)=\left[N^{-1} \sum_{i=1}^{N} g\left(w_{i}, \theta\right)\right]^{\prime} \widehat{\Lambda}^{-1}\left[N^{-1} \sum_{i=1}^{N} g\left(w_{i}, \theta\right)\right]
$$

Following the notation of Wooldridge (2002), $\theta$ is the vector of unknown coefficients. In this analysis, this vector includes the component for adverse selection risk $\left(\alpha_{i, t}\right)$, the component for inventory holding risk $\left(\beta_{i, t}\right)$, and the trade direction reversal probability $\left(\pi_{i, t}\right)$. The order processing cost component is computed as the residual cost, after subtracting $\alpha_{i, t}$ and $\beta_{i, t}$ from one, since the three cost shares must add up to $100 \% . g\left(w_{i}, \theta\right)$ is an ( $L \times 1)$ vector of moment functions (or orthogonality conditions). These functions 
are non-linear and given by:

1. $g_{1}=\left(Q_{i, t-1}-\left(1-2 \pi_{i, t}\right) Q_{i, t-2}\right) Q_{i, t-2}$

2. $g_{2}=\left(Q_{i, t-1}-\left(1-2 \pi_{i, t}\right) Q_{i, t-2}\right) S_{i, t-1}$

3. $g_{3}=\left(Q_{i, t-1}-\left(1-2 \pi_{i, t}\right) Q_{i, t-2}\right) S_{i, t-2}$

4. $g_{4}=\left(\Delta M_{i, t}-\left(\alpha_{i, t}+\beta_{i, t}\right) \frac{S_{i, t-1}}{2} Q_{i, t-1}+\alpha_{i, t} \frac{S_{i, t-2}}{2}\left(1-2 \pi_{i, t}\right) Q_{i, t-2}\right) S_{i, t-1}$

5. $g_{5}=\left(\Delta M_{i, t}-\left(\alpha_{i, t}+\beta_{i, t}\right) \frac{S_{i, t-1}}{2} Q_{i, t-1}+\alpha_{i, t} \frac{S_{t} i, t-2}{2}\left(1-2 \pi_{i, t}\right) Q_{i, t-2}\right) S_{i, t-2}$

6. $g_{6}=\left(\Delta M_{i, t}-\left(\alpha_{i, t}+\beta_{i, t}\right) \frac{S_{i, t-1}}{2} Q_{i, t-1}+\alpha_{i, t} \frac{S_{i, t-2}}{2}\left(1-2 \pi_{i, t}\right) Q_{i, t-2}\right)\left(Q_{i, t-1}-(1-2 \pi) Q_{i, t-2}\right)$.

$\widehat{\Lambda}$ is the optimal weighting matrix which is similarly determined following Wooldridge (2002):

$$
\widehat{\Lambda} \equiv \frac{1}{N} \sum_{i=1}^{N}\left[g\left(w_{i}, \theta\right)\right]\left[g\left(w_{i}, \theta\right)\right]^{\prime} .
$$

We estimate adverse selection costs, inventory holding costs, and order processing costs on a monthly basis for all stocks having at least 15 daily observations in a given month. We implement the GMM decomposition code in Matlab and obtain $\alpha$ and $\beta$ coefficients for each month and stock. We then assemble the estimation results across stocks and time to create a new, monthly panel, to which we add stock-specific, end-of-month stock prices, relative spreads, and total number of shares traded over the month.

\subsection{Adverse Selection Costs as the Main Driver of Illiquidity}

In line with our hypotheses, we find that adverse selection costs contributed most to total spreads throughout the period (Figure 9). During the panic, all three cost components rose sharply: information costs rose from $\$ 0.007$ to $\$ 0.02$, inventory holding costs increased from $\$ 0.003$ to $\$ 0.009$, and order processing costs from $\$ 0.004$ to $\$ 0.01$. Though all cost components experienced an increase of the same order of magnitude, the adverse selection component was twice as large as the other two cost types both before and during the Panic of 1907. 

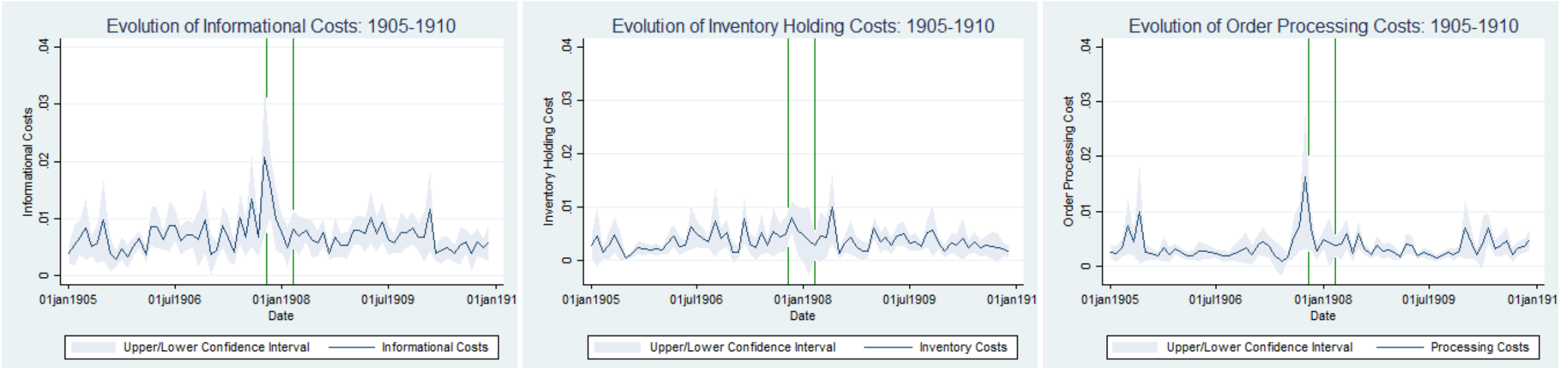

Figure 9: Informational Costs, Inventory Costs, and Order Processing Costs: 1905-1910 
The findings accord well with the information story of the Panic of 1907. Since presumably information was largely negative during the crisis, securities prices declined and in the process significantly reduced the collateral value of stocks and, thus, added to the costs of holding inventory. ${ }^{31}$ Moreover, to the extent that there were significant fixed cost components in order processing, the decline in stock prices would cause an increase in relative order processing costs. Hence, both inventory holding costs and order processing costs were closely related to information costs during the crisis of 1907.32 Nonetheless, in line with our hypothesis, uncertainty and information asymmetry continued to play the dominant role in market illiquidity during the Panic.

We also find support for Hellwig and Zhang (2012), that is, that the role of information changes from the onset of a crisis to the end. In the case of the Panic of 1907, we see an increase of informational costs from the onset of the Panic on. However, the real peak of rumor contagion is reached when the Panic is already evolving (i.e., late October 1907), not during the earlier phases of the increasingly severe bear market of August and September. This suggests that the spreading informational uncertainty (i.e., rumors) affected a large proportion of the market and ratcheted up during the crisis. Obviously, in the case of information produced and propagated through rumors, the process may create more noisy information-or misinformation-and thereby reduce market efficiency (Dang et al. (2010)).

To more rigorously test our hypotheses about adverse selection and its role in market illiqudity during the panic, we estimate panel quantile regressions for each of the three estimated components of spreads, normalized by end-of-month stock price. We control for the (lagged) price level, contemporaneous volatility, and lagged call money rates, and then include an indicator for the months of the crisis (October and November 1907), as follows:

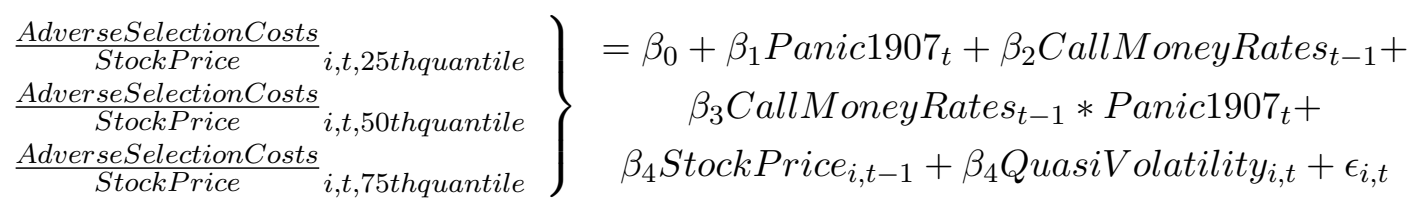

\footnotetext{
${ }^{31}$ Stocks were widely used as collateral by the Clearinghouse in the period under study.

${ }^{32}$ Due to data limitations we can estimate spread components only on a monthly frequency for a subset of stocks (two thirds of the overall data set). Hence, we cannot meaningfully test inter-temporal (Granger-)causation between the different spread components.
} 


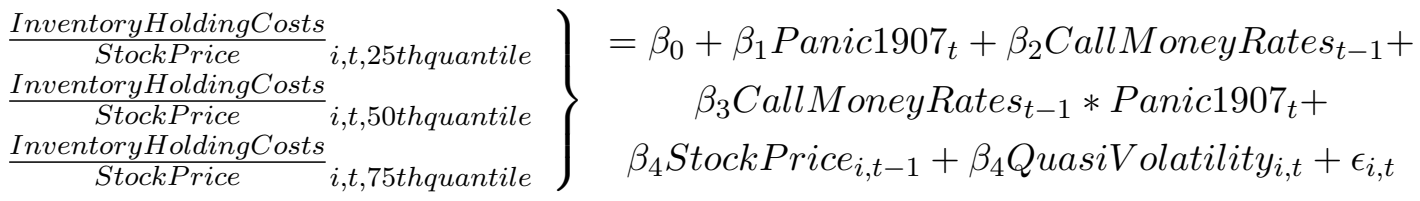

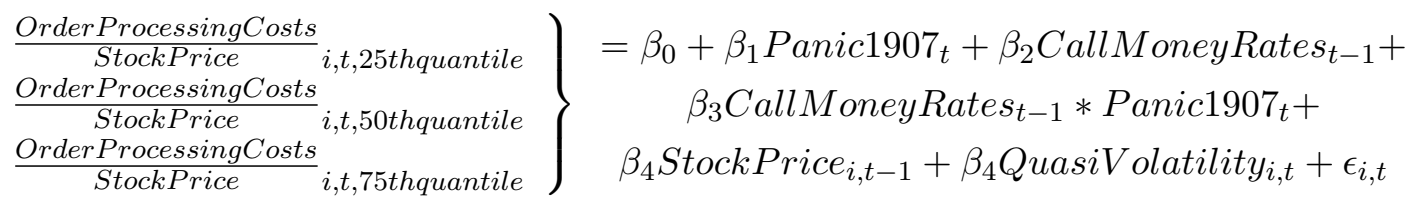

Analyzing the adverse selection component (Table 6.a) we find that asset price uncertainty (quasi-volatility) remains the strongest correlate across all quantiles of adverse selection costs, and the effect increases over quantiles. Prior month call money rates also relate to higher adverse selection costs during the Panic, particularly for the moderate to less liquid and presumably more opaque stocks. Outside of the Panic, lagged call money rates do not relate to adverse selection costs at all. Hence funding illiquidity particularly affects less liquid stocks in periods of stress.

Inventory holding and order processing costs show little correlation with the panic or with call money rates (Table 6.b and Table 6.c). Overall the explanatory power is lower than for the averse selection cost component.

\subsection{Cross Sectional Evidence on Opaqueness and Market Illiq- uidity}

In order to analyze in more detail how information opaqueness influenced illiquidity in the market, we divide the sample of stocks according to their expected opaqueness levels. We hypothesize that adverse selection risk was highest in the most opaque and rumorridden sectors (especially mining companies), among stocks that are ex ante traded with wider total spreads, and for stocks that traded in the NYSE Unlisted department, where companies avoided both the vetting process required for official listing and the exchange's disclosure rules once listed.

First, we compare bid-ask spreads and the three cost factors by industry. As expected, the panic hurt the relatively opaque mining stocks' liquidity the most. Spreads of mining 
companies rose from about seven percent before the crisis to about 15 percent during the height of the panic (Figure 10). The sharp rise in illiquidity results largely from adverse selection risk: adverse selection costs (in dollar-terms) triple from $\$ 0.02$ to $\$ 0.1$ shortly before and during the Panic, the steepest increase across all industries. Most importantly, adverse selection costs remain high, even after rescue measures took place. This finding indicates that the rumor-based crisis infected mining stocks severely enough to persist over the longer term.

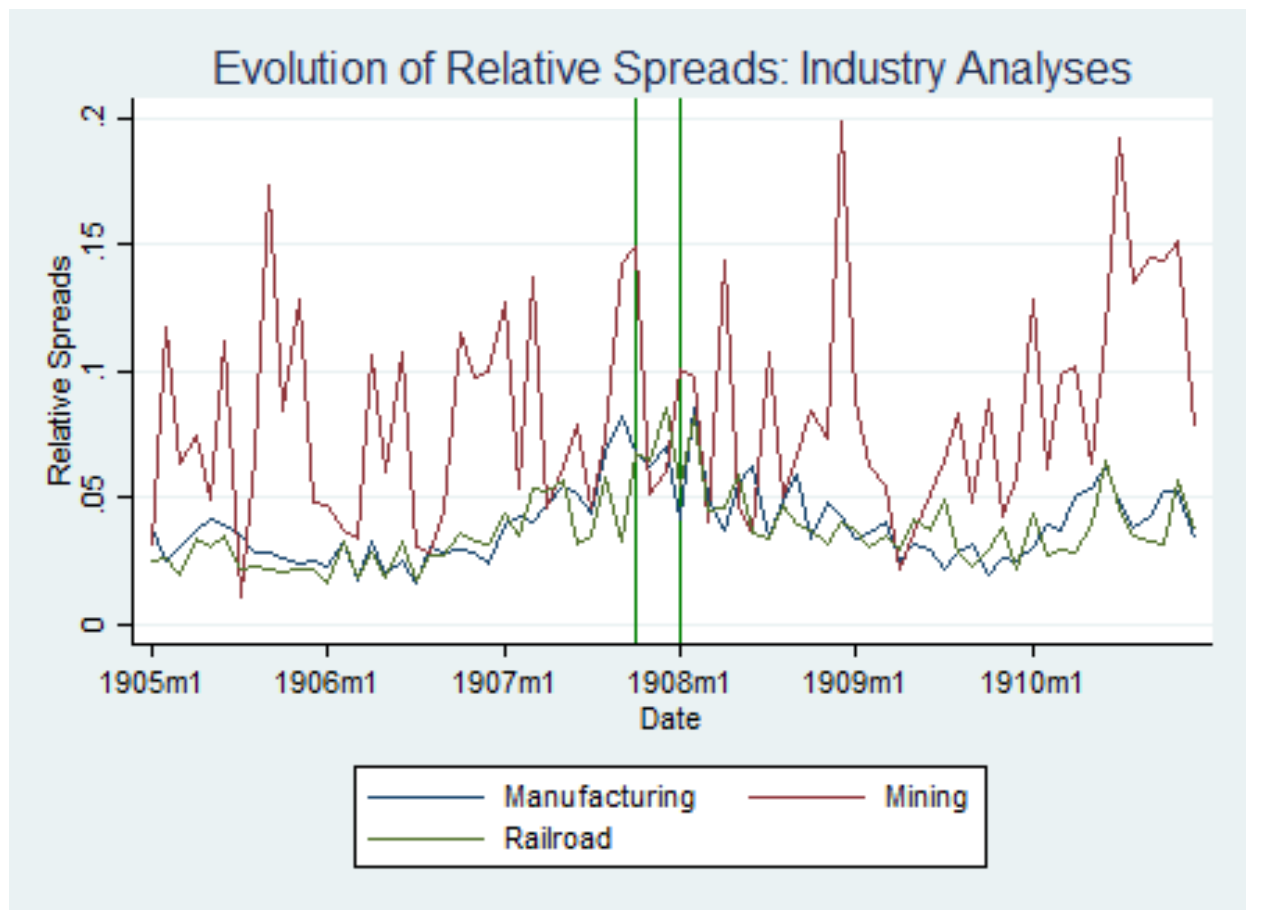

Figure 10: Average Relative Industry Bid-Ask Spreads: 1905-1910

On the flip side, we also confirm that stocks in the sectors that published accounting information on a regular basis (such as the railroad and utilities sectors), and whose accounting systems were relatively transparent due to federal regulatory burden, experience lower adverse selection costs compared to other industries, such as manufacturing or mining. The railroad sector's informational costs were the lowest and remained at the same level during the crisis. Relative transparency, therefore, yields lower adverse selection risk and increased stock market liquidity.

We further conjecture that, regardless of sector identity, illiquid or opaque (e.g. low volume, high price impact, or unlisted) stocks were affected disproportionally by informational costs. To test this presumption, we categorize the stocks as "liquid" if they fall 
into the lowest quartile of relative spreads and "illiquid" if they fall into the highest quartile of that distribution. As we predict, the most illiquid stocks experience significantly greater increases in informational costs, inventory costs, and order processing costs than liquid ones (Figure 11). All three spread components are more than three times larger for illiquid stocks than for liquid stocks. Furthermore, for illiquid stocks, informational costs increased during the panic, whereas the other two cost types even declined slightly during the crisis. The results suggest that illiquid stocks are particularly subject to adverse selection costs during a liquidity freeze.

Finally, we find similar results in comparing listed and unlisted companies: informational costs hit the latter more than the former (Figure 12). Unlisted stocks generally suffer more from higher informational costs due to the lack of certification and absence of disclosure rules, so the adverse selection problems should intensify during a financial crisis. Indeed, information costs were especially elevated during the last quarter of 1907. It also took longer for adverse selection risk to decrease in unlisted stocks compared to listed stocks.

Together, these results suggest that investments in companies that operated with greater transparency and liquidity - whether due to listing rules or regulatory disclosure requirements - indeed served as a hedge against adverse selection risk and especially so in times of heightened uncertainty. 

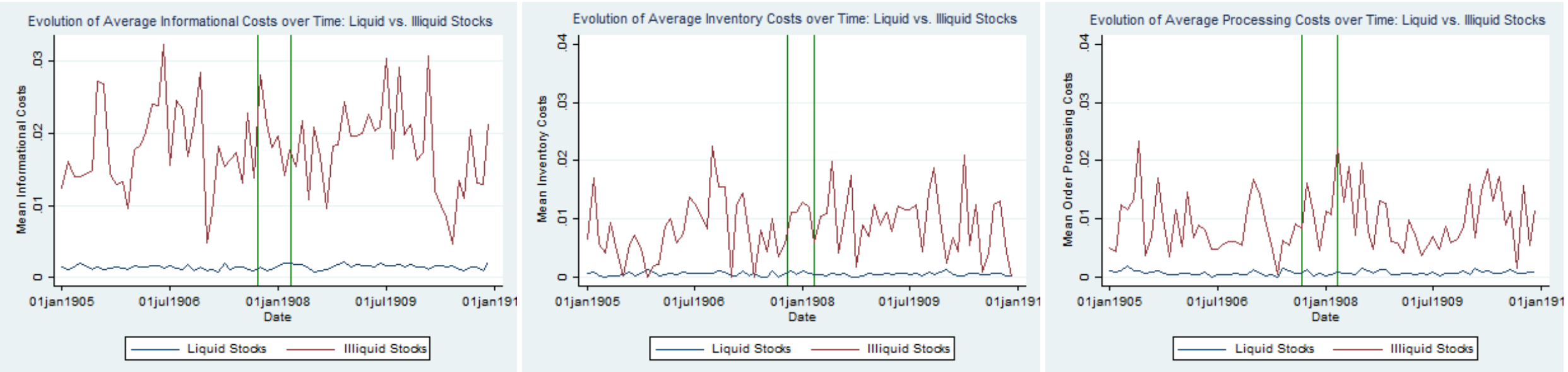

Figure 11: Informational Costs, Inventory Costs, and Order Processing Costs: Liquid vs. Illiquid Stocks 

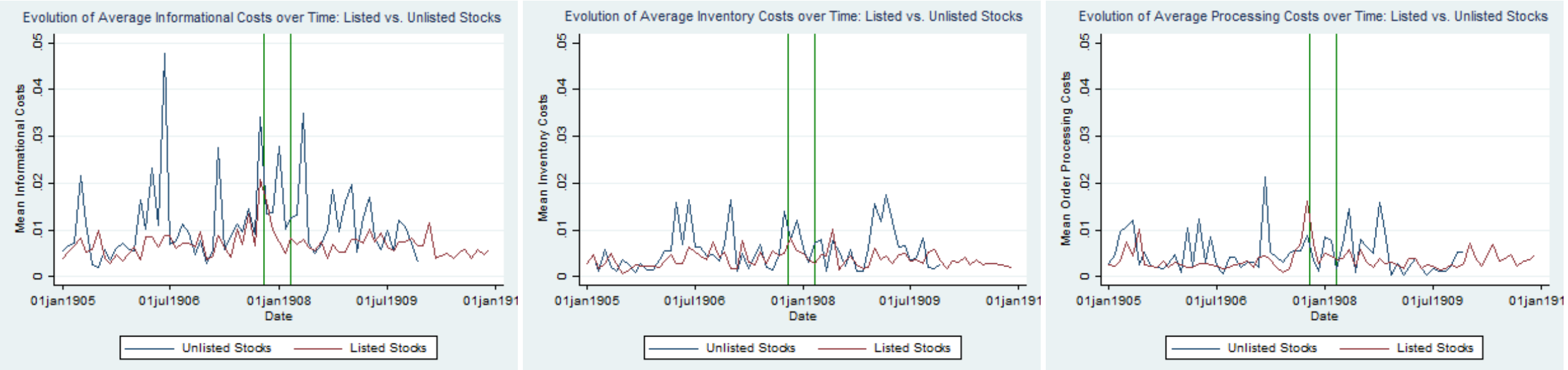

Figure 12: Infomational Costs, Inventory Costs, and Order Processing Costs: Listed vs. Unlisted Stocks 


\section{Adverse Selection as a Factor in Asset Pricing}

Now that we have a clear picture of the components of spreads and the impact on these transactions costs stemming from opaqueness and illiquidity, we can assess the extent to which the various cost components enter into asset pricing decisions. We thus revisit our four-factor asset pricing model of Section 5 replacing the relative spread with the three spread components: adverse selection costs, inventory management costs, and order processing costs. The analysis otherwise follows the methodology outlined in Section 5. Since the components of the spread decomposition exhibit a low degree of correlation with each other, they can be considered as largely independent contributing factors.

Key to our understanding of opaqueness-driven illiquidity, we find that the adverse selection (informational) risk factor is positive and statistically significant for excess returns and provides far more explanatory power than either of the two other cost components (Table 7). Indeed, the order processing component provides one third the influence of the informational factor, and the inventory management component is not priced in our model. These results underscore the high relevance of information risk and the awareness of such risk on the part of market participants during this relatively early (and unregulated) period of stock market and corporate governance development.

It is also interesting to note that the inclusion of the microstructure components in our asset pricing analysis yields a market price of risk of about 0.7 percent. The SMB and HML factors are similar to those found in Chabot et al. (2014). ${ }^{33}$ Due to the data limitations on the construction of the information measure, the cross section loses about one third of observations. Hence a meaningful comparison of explanatory power is not feasible.

In order to test for the robustness of the asset pricing results using the adverse selection cost component, we test the same model with two alternative measures of information risk: 1. Kyle's Lambda, based on Kyle (1985) and 2. the adverse selection measure estimated from effective spreads, based on Hendershott et al. (2011).

In order to measure Kyle's lambda, we estimate the following model:

$$
p_{t}=f_{t}+\lambda Q_{t}+\epsilon_{t}
$$

where $\lambda^{-1}$ is a measure of market depth. Taking first differences we get:

\footnotetext{
${ }^{33}$ Our analysis actually suggests that Chabot et al. (2014) can be improved by explicitly allowing for market microstructure information.
} 

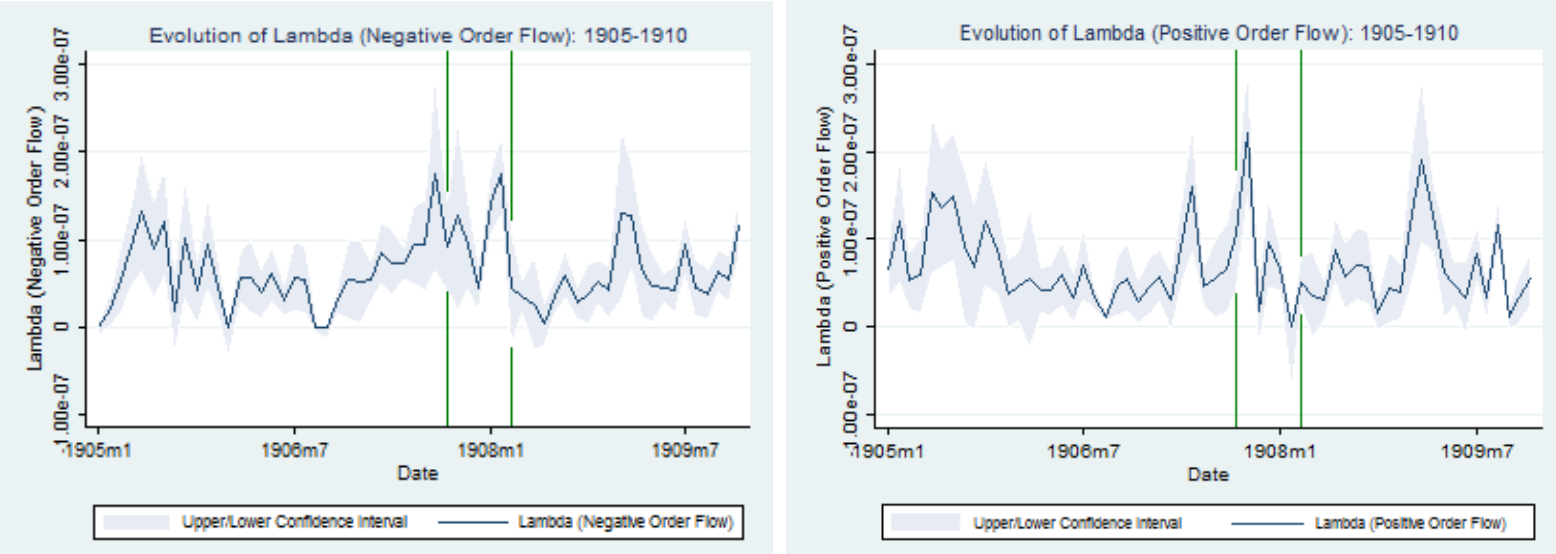

\section{Figure 13: Evolution of Lambda for Negative and Positive Order Flow}

$$
\Delta p_{t}=\Delta f_{t}+\lambda \Delta Q_{t}+\Delta \epsilon_{t}
$$

Note that we use the first transaction price of each day, because opening prices are generally less noisy than closing mid-quotes, which are usually relatively wide; thus introducing noise into the estimation of informational risk. We estimate lambda for both positive and negative order flow. Our estimation shows very small values of Lambda (Figure 13), but note that the values clearly rise prior to the peak of the crisis.

We next estimate the adverse selection measure from Hendershott et al. (2011), based on the effective spread as well as transactions prices $p_{t}$, mid quote $m_{t}$, and the trade direction indicator variable $q_{t}$.

$$
E S=q_{t} \frac{m_{t+\Delta}-m_{t}}{m_{t}}+q_{t} \frac{p_{t}-m_{t+\Delta}}{m_{t}}
$$

The first expression captures the adverse selection component; the second part denotes the residual that cannot be explained by the adverse selection component. Delta denotes a time-increment (lead or lag). Recent studies using high frequency data usually use a time increment of two to five minutes. Given the daily frequency of our data - the highest available for this period - we have to work with a lag/lead of one day. As with all of our previous estimates of informational risk, this measure rises shortly before and during the Panic (Figure 14).

We then go on to test these measures in the same asset pricing framework used above and find that they prove significant as priced risk factors, in line with the results using the 


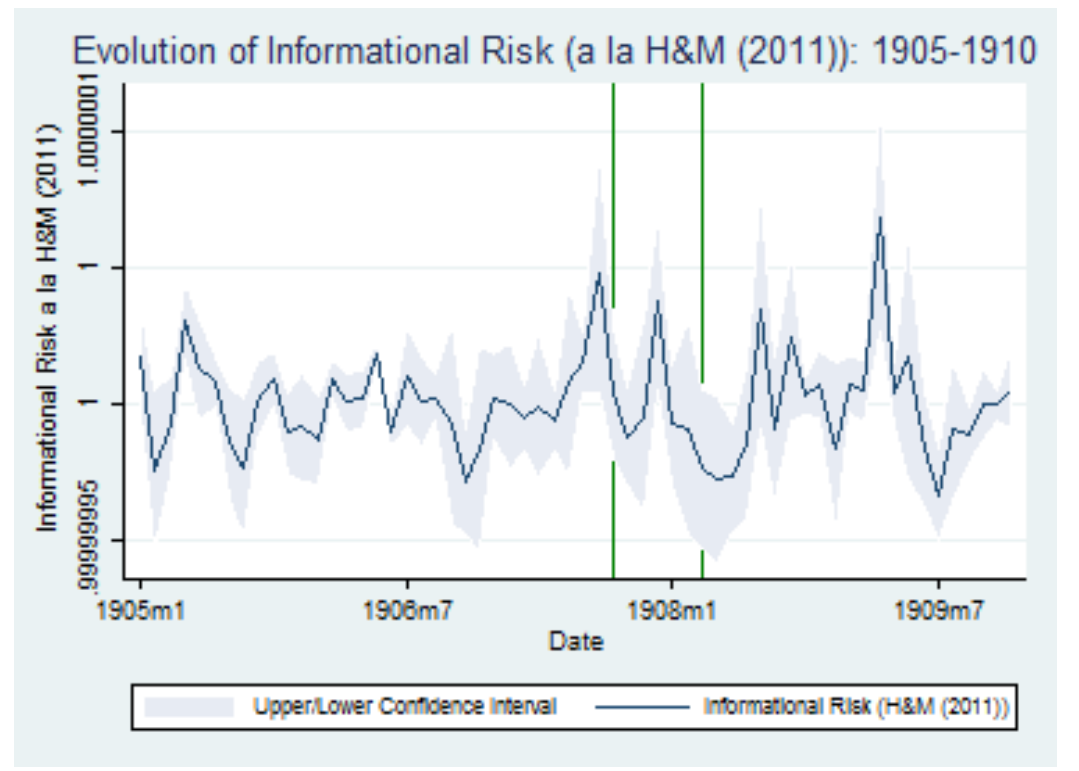

Figure 14: Evolution of Informational Risk according to Hendershott et al. (2011)

earlier proxies for adverse selection and overall liquidity (Table 7). Results on the SMB and HML factors differ from earlier results. In particular, when we include the measure of Hendershott et al. (2011), the HML factor (value) becomes insignificant. Importantly, as with our previous model with adverse selection risk, we find a positive market price of risk, varying around 0.8 percent, along with a positive market price of informational risk, which is positive except for the Kyle model. Together, the results provide robust evidence that asymmetric information risk was priced during this relatively early period in market history.

\section{Conclusion}

Our analysis offers several new insights into the role of information in financial markets, and in particular, how critical a role information transparency plays in mitigating adverse selection problems that destabilize markets. The period of our study, 1905-1910, surrounds one of the worst financial crises in over 100 years and provides a unique window on the performance of self-regulated asset markets operating under constrained information in the face of uncertainty shocks from unverifiable rumors.

We trace stock market illiquidity to funding illiquidity during the peak of the crisis and more broadly demonstrate the liquidity premium demanded in the market. We then decompose equity bid-ask spreads into their underlying cost components and find that 
adverse selection costs play a dominant role in transaction costs. Though all of our measures of liquidity evidence severe deterioration of market quality, we find that informational risk contributes the largest share of the wedge between bid and ask prices. Importantly, short-term cash infusions did not have a lasting effect on trading volume, even though the different risk factors recovered.

Our results demonstrate that an ostensibly short-run liquidity freeze happening in an opaque market setting can severely harm confidence in financial markets over extended periods, constraining liquidity far beyond the most acute phase of the panic. We show further that asymmetric information problems play out - as the theory suggests - in predictable cross-sectional variation in illiquidity. In particular, the liquidity crisis hit the mining sector most severely, because it lay at the heart of the crisis - both in terms of illiquidity and in terms of heightened informational risk. The mining sector also ranked among the least transparent sectors of the economy and, along with many manufacturing enterprises, provided sparse information to investors. We find that these types of stocks suffered most from adverse selection costs, while the regulated and more transparent utilities and railroads suffered the least. Moreover, both extremely illiquid stocks as well as stocks traded in the NYSE's more opaque Unlisted department also suffered significantly more during the Panic than well-certified (listed) and liquid stocks.

Finally, our analysis generates important insights for asset pricing. In particular, we show that it is possible to predict asset prices based on estimated components of bid-ask spreads. Informational costs incur risk premia above and beyond the standard market beta and Fama-French factors. Hence, the predictability of transaction costs and liquidity also implies predictability of asset prices. Thus, asset prices are informationally efficient in, at most, a weak sense. Our findings demonstrate the first order relevance of market microstructure and liquidity components for asset pricing.

From a policy standpoint, our results are particularly interesting, because the Panic of 1907 marks a turning point in the history of the U.S. financial system and the rise of the regulated era. The severity of the Panic of 1907 brought calls for reform of the financial system, with a particular focus on curbing potentially destabilizing activities in the stock markets and the need for a lender of last resort: themes that echo in today's debates over financial regulation. Most of the first phase of regulatory activity focused on bank liquidity backstops. Consequently, on May 28, 1908, Congress passed the Aldrich-Vreeland Act that provided for emergency currency to infuse liquidity into the system when widespread insolvency threatened. Additionally, the law introduced the National Monetary Commis- 
sion and charged it with investigating the Panic of 1907 and recommending measures to regulate capital markets and the banking system (Calomiris and Gorton (1991)). The Commission submitted its final report in 1912 and on December 23, 1913, Congress passed the Federal Reserve Act. Thus, the 1907 crisis stands as the last major crisis without an official institution to coordinate liquidity support in periods of financial distress, and ultimately the stimulus for the foundation of the Federal Reserve System. ${ }^{34}$

Politicians also held up the Panic of 1907 as an example of Wall Street excess and dishonesty and used it to motivate the famous Money Trust hearings in Congress. That investigation produced volumes of testimony by Wall Street insiders and led to the Clayton Antitrust Act. In New York, the Governor appointed a committee to study the crisis and recommend reforms to the financial markets, which led to tighter control over access to trading at the NYSE. These early regulatory steps made little in-road into the problem of information opaqueness that had exacerbated (if not outright caused) the crisis, but the new regulations did lay the foundation for more far-reaching government oversight of markets and corporate governance, such as the Securities and Exchange Commission (SEC), created a few decades later. In this sense, the Panic of 1907 ultimately put an end to unregulated securities markets and opaque corporate accounting in the United States.

\footnotetext{
${ }^{34}$ We consider the situation in the summer of 1914, as an impending crisis, but one that was staved off in part due to the lessons of 1907 and the creation of a liquidity backstop in Aldrich-Vreeland. Fohlin (2016) provides an in-depth study of market liquidity during the lead-up to the war and global stock market closures, as well as during the month following the reopening of the NYSE in December 1914.
} 


\section{References}

Acharya, V. V. and Pedersen, L. H. (2005). Asset Pricing with Liquidity Risk. Journal of Financial Economics, 77(2):375-410.

Archambault, J. J. and Archambault, M. (2005). The Effect of Regulation on Statement Disclosures in the 1915 Moody's Manuals. The Accounting Historians Journal, pages $1-22$.

Archambault, J. J. and Archambault, M. E. (2011). Earnings Management among Firms during the Pre-sec Era: A Benford's Law Analysis. The Accounting Historians Journal, pages $145-170$.

Bernardo, A. E. and Welch, I. (2004). Liquidity and Financial Market Runs. The Quarterly Journal of Economics, pages 135-158.

Bernstein, A., Hughson, E., and Weidenmier, M. D. (2014). Counterparty Risk and the Establishment of the New York Stock Exchange Clearinghouse. Technical report, National Bureau of Economic Research.

Bruner, R. F. and Carr, S. D. (2008). The Panic of 190\%: Lessons learned from the market's perfect storm. John Wiley \& Sons.

Brunnermeier, M. K. and Pedersen, L. H. (2009). Market liquidity and funding liquidity. Review of Financial studies, 22(6):2201-2238.

Burns, A. F., Mitchell, W. C., et al. (1946). Measuring business cycles. NBER Books.

Calomiris, C. W. and Gorton, G. (1991). The Origins of Banking Panics: Models, Facts, and Bank Regulation. In Financial Markets and Financial Crises, pages 109-174. University of Chicago Press.

Chabot, B., Ghysels, E., and Jagannathan, R. (2014). Momentum trading, return chasing, and predictable crashes. Technical report, National Bureau of Economic Research.

Chang, B. (2012). Adverse Selection and Liquidity Distortion. Available at SSRN $170199 \%$.

Cochrane, J. (2005). Asset Pricing. Princeton University Press.

Dang, T. V., Gorton, G., and Holmström, B. (2010). Financial Crises and the Optimality of Debt for Liquidity Provision. Unpublished working paper. Yale School of Management.

Davis, L. E. and Gallman, R. E. (2001). Evolving Financial Markets and International Capital Flows: Britain, the Americas, and Australia, 1865-1914. Cambridge University Press.

Donaldson, R. G. (1992). Sources of Panics: Evidence from the Weekly Data. Journal of Monetary Economics, 30(2):277-305.

Fama, E. F. and French, K. R. (1992). The cross-section of expected stock returns. the Journal of Finance, 47(2):427-465. 
Fama, E. F. and French, K. R. (1993). Common risk factors in the returns on stocks and bonds. Journal of financial economics, 33(1):3-56.

Fama, E. F. and MacBeth, J. D. (1973). Risk, Return, and Equilibrium: Empirical Tests. The Journal of Political Economy, pages 607-636.

Fohlin, C. (2015). A New Database of Transactions and Quotes in the NYSE, 1900-25 with Linkage to CRSP. In Johns Hopkins Mimeo.

Fohlin, C. (2016). Complex news and investor uncertainty: The NYSE during the European Crisis of 1914. Working Paper.

Fohlin, C., Gehrig, T., and Brünner, T. (2008). Liquidity and Competition in Unregulated Markets: The New York Stock Exchange Before the SEC. DP 101, Collegio Carlo Alberto.

Frydman, C., Hilt, E., and Zhou, L. Y. (2012). Economic Effects of Runs on Early 'Shadow Banks': Trust Companies and the Impact of the Panic of 1907. Technical report, National Bureau of Economic Research.

Gehrig, T. and Haas, M. (2015). Lehman Brothers: Did Markets Know? Available at SSRN 2408489.

Gorton, G. (1988). Banking Panics and Business Cycles. Oxford economic papers, pages $751-781$.

Hansen, L. (1982). Large Sample Properties of Generalized Method of Moments Estimators. Econometrica: Journal of the Econometric Society, pages 1029-1054.

Hansen, L. and Singleton, K. (1982). Generalized Instrumental Variables Estimation of Nonlinear Rational Expectations Models. Econometrica: Journal of the Econometric Society, pages 1269-1286.

He, Z. and Manela, A. (2014). Information Acquisition in Rumor-Based Bank Runs. The Journal of Finance.

Hellwig, K.-P. and Zhang, S. (2012). Market Runs: Liquidity and the Value of Information.

Hendershott, T., Jones, C. M., and Menkveld, A. J. (2011). Does algorithmic trading improve liquidity? The Journal of Finance, 66(1):1-33.

Holmström, B. and Tirole, J. (2001). An analysis of changes in specialist inventories and quotations.

Huang, R. and Stoll, H. (1997). The Components of the Bid-ask Spread: A General Approach. Review of Financial Studies, 10(4):995-1034.

Kindleberger, C. P. (1978). Manias, Panics and Crashes: A History of Financial Crises. Basic Books, New York City, NY. 
Kindleberger, C. P. and Aliber, R. Z. (2011). Manias, Panics and Crashes: A History of Financial Crises. Palgrave Macmillan.

Kyle, A. (1985). Continuous Auctions and Insider Trading. Econometrica, 53(6):13151335.

Li, Z. and Ma, K. (2016). A theory of endogenous asset fire sales, bank runs and contagion. In Warwick Mimeo.

Macaulay, F. R. et al. (1938). Some theoretical problems suggested by the movements of interest rates, bond yields and stock prices in the united states since 1856. NBER Books.

Moen, J. and Tallman, E. (1992). The Bank Panic of 1907: The Role of Trust Companies. Journal of Economic History, 52(3):611-30.

Mulherin, J., Netter, J., and Overdahl, J. (1991). Prices are Property: the Organization of Financial Exchanges from a Transaction Cost Perspective. JL E Econ., 34:591.

Odell, K. A. and Weidenmier, M. D. (2004). Real shock, monetary aftershock: The 1906 san francisco earthquake and the panic of 1907. The Journal of Economic History, 64(04):1002-1027.

Parker, R. E. and Whaples, R. M. (2013). Routledge Handbook of Major Events in Economic History. Routledge.

Pástor, L. and Stambaugh, R. F. (2003). Liquidity Risk and Expected Stock Returns. Journal of Political Economy, 111(3):642-685.

Rodgers, M. T. and Payne, J. E. (2012). An Overlooked Central Bank Rescue: How the Bank of France Ended the American Financial Crisis of 1907. Journal of Economic History.

Sivakumar, K. and Waymire, G. (2003). Enforceable Accounting Rules and Income Measurement by Early $20^{\text {th }}$ Century Railroads. Journal of Accounting Research, 41(2):397432.

Sivakumar, K. N. and Waymire, G. (1993). The Information Content of Earnings in a Discretionary Reporting Environment: Evidence from NYSE Industrials, 1905-10. Journal of Accounting Research, pages 62-91.

Sprague, O. M. (1908). The american crisis of 1907. The Economic Journal, 18(71):353372.

Sprague, O. M. W. (1910). History of crises under the national banking system, volume 538. US Government Printing Office.

Tallman, E. W. and Moen, J. R. (1990). Lessons from the Panic of 1907. Economic Review. 
Tallman, E. W. and Moen, J. R. (2012). Liquidity Creation without a Central Bank: Clearing House Loan Certificates in the Banking Panic of 1907. Journal of Financial Stability, 8(4):277-291.

Tallman, E. W. and Moen, J. R. (2014). The Transmission of the Financial Crisis in 1907: An Empirical Investigation.

Wilson, B. K. and Rodgers, M. T. (2011). Systemic Risk, Missing Gold Flows and the Panic of 1907. The Quarterly Journal of Austrian Economics.

Wooldridge, J. (2002). Econometric Analysis of Cross Section and Panel Data. The MIT press. 


\section{Tables}

Table 1: Descriptive Statistics of Daily Data

\begin{tabular}{|c|c|c|c|c|c|c|}
\hline Variables & Mean & Median & Std & Q25 & Q75 & Observations \\
\hline Relative Bid-Ask Spread (1905-1910) & 0.020 & 0.008 & 0.058 & 0.003 & 0.020 & 161.810 \\
\hline Number of Shares Traded (1905-1910) & 7521 & 800 & 24819 & 200 & 3400 & 161.810 \\
\hline High Price (1905-1909) & 75.48 & 55.00 & 61.99 & 28.25 & 113.00 & 132.646 \\
\hline Low Price (1905-1909) & 74.64 & 54.00 & 61.63 & 27.00 & 111.75 & 132.646 \\
\hline Last Price (1905-1910) & 78.62 & 56.75 & 78.53 & 29.75 & 110.00 & 161.810 \\
\hline Quasi Volatility (1905-1909) & 0.015 & 0.009 & 0.036 & 0.00 & 0.020 & 132.590 \\
\hline High Call Money Rates (Aug. 1, 07-May 29, 08) & 0.088 & 0.030 & 0.165 & 0.020 & 0.08 & 206 \\
\hline Capital Stock & $6.01 \mathrm{e}+07$ & $3.00 \mathrm{e}+07$ & $1.01 \mathrm{e}+08$ & $1.50 \mathrm{e}+07$ & $6.52 \mathrm{e}+07$ & 7527 \\
\hline Book-to-Market Ratio & 3.71 & 1.73 & 7.57 & 0.90 & 3.74 & 7527 \\
\hline
\end{tabular}

Table 2: Descriptive Statistics of Monthly Data

\begin{tabular}{lcccccc}
\hline Variables & Mean & Median & Std & Q25 & Q75 & Observations \\
\hline \hline Gold Stock (Billion \$) & 1.50 & 1.61 & 0.17 & 1.34 & 1.64 & 72 \\
Adverse Selection Component & 0.50 & 0.52 & 0.23 & 0.38 & 0.64 & 1740 \\
Inventory Holding Component & 0.26 & 0.21 & 0.25 & 0.02 & 0.43 & 1740 \\
Order Processing Component & 0.24 & 0.18 & 0.23 & 0.05 & 0.37 & 1740 \\
\hline
\end{tabular}




\section{Table 3: Stock Market Illiquidity During the Panic of 1907}

This table reports the results of quantile regression of relative bid-ask spreads on time indicator variables for the Panic period and controls for volatility and share prices. The sample includes the panel of all traded NYSE stocks at daily frequency from 1905 to 1909, and the table reports results for the 1st, 2nd, and 3rd quartiles. Relative bid-ask spread is the difference between ask and bid prices divided by the average of ask and bid prices. Quasi-volatility is defined as the highest transaction price on a given day minus the lowest transaction price on that same day, divided by the last transaction price (note that we exclude observations for which quasi-volatility equals zero). The "Height of Panic" indicator variable takes the value of one during the height of the 1907 Panic, namely from October 22, 1907, to November 9, 1907, and zero otherwise. "Crisis" denotes the remainder of the Panic of 1907, namely the period of September 30, 1907, to October 8, 1907, and November 10, 1907, to January 31, 1908. T-statistics use heteroskedasticity-adjusted standard errors and are reported in parentheses below the coefficient estimates. The symbols $* * *, * *$ and $*$ indicate statistical significance at the $1 \%, 5 \%$, and $10 \%$ levels, respectively.

\begin{tabular}{lccc}
\hline & $(1)$ & $(2)$ & $(3)$ \\
VARIABLES & Rel. Spread 1st quartile & Rel. Spread Median & Rel. Spread 3rd quartile \\
\hline \multirow{2}{*}{ Height of Panic } & $0.0042^{* * *}$ & $0.011^{* * *}$ & $0.027^{* * *}$ \\
& $(5.37)$ & $(5.09)$ & $(9.97)$ \\
Crisis & $0.0019^{* * *}$ & $0.0049^{* * *}$ & $0.013^{* * *}$ \\
& $(4.02)$ & $(4.65)$ & $(5.44)$ \\
Stock Price & $-0.000026^{* * *}$ & $-0.000034^{* * *}$ & $-0.000045^{* * *}$ \\
& $(-5.45)$ & $(-3.12)$ & $(-5.00)$ \\
Quasi Volatility & $0.022^{* *}$ & $0.093^{* * *}$ & $0.26^{* * *}$ \\
& $(2.39)$ & $(4.65)$ & $(4.80)$ \\
Constant & $0.0050^{* * *}$ & $0.0076^{* * *}$ & $0.013^{* * *}$ \\
& $(9.29)$ & $(6.99)$ & $(8.92)$ \\
\hline Observations & 99,090 & 99,090 & 99,090 \\
Pseudo R & 0.049 & 0.042 & 0.035 \\
\hline \hline
\end{tabular}




\section{Table 4: Funding Illiquidity and Market Illiquidity During the Panic of 1907}

This table reports the results of quantile regression of relative bid-ask spreads on high call money rates and controls for volatility, share price, and panic indicator variables. The sample includes the panel of all traded NYSE stocks at daily frequency from August 1, 1907 to May 31, 1908 , and the table reports results for the 1st, 2nd, and 3rd quartiles. Relative bid-ask spread is the difference between ask and bid prices divided by the average of ask and bid prices. Quasi-volatility is defined as the highest transaction price on a given day minus the lowest transaction price on that same day, divided by the last transaction price (note that we exclude observations for which quasi-volatility is zero). The "Height of Panic" indicator variable takes the value of one during the height of the 1907 Panic, namely from October 22, 1907, to November 9, 1907, and zero otherwise. "Crisis" denotes the remainder of the Panic of 1907, namely the period of September 30, 1907, to October 21, 1907, and November 10, 1907, to January 31, 1908. T-statistics use heteroskedasticity-adjusted standard errors and are reported in parentheses below the coefficient estimates. The symbols $* * *, * *$ and $*$ indicate statistical significance at the $1 \%, 5 \%$, and $10 \%$ levels, respectively.

\begin{tabular}{lccc}
\hline & $(1)$ & $(2)$ & $(3)$ \\
VARIABLES & & & \\
& Rel. Spread 1st quartile & Rel. Spread Median & Rel. Spread 3rd quartile \\
\hline Height of Panic & $0.0034^{* *}$ & $0.0049^{* *}$ & $0.0089^{*}$ \\
& $(2.39)$ & $(2.00)$ & $(1.64)$ \\
Crisis & 0.00038 & $0.0025^{* * *}$ & $0.0039^{* *}$ \\
& $(0.88)$ & $(3.63)$ & $(2.53)$ \\
High Call Money Rates & -0.00041 & 0.0038 & $0.019^{*}$ \\
& $(-0.32)$ & $(1.39)$ & $(1.70)$ \\
Stock Price & $-0.000059^{* * *}$ & $-0.000086^{* * *}$ & $-0.00012^{* * *}$ \\
& $(-4.32)$ & $(-4.07)$ & $(-4.03)$ \\
Quasi Volatility & 0.033 & $0.10^{* * *}$ & $0.28^{* * *}$ \\
Constant & $(1.30)$ & $(2.78)$ & $(6.32)$ \\
& $0.0082^{* * *}$ & $0.014^{* * *}$ & $0.024^{* * *}$ \\
\hline Observations & $(6.79)$ & $(6.92)$ & $(7.07)$ \\
Pseudo R & 12,180 & 12,180 & 12,180 \\
\hline \hline
\end{tabular}




\section{Table 5: Asset Pricing with a Liquidity Factor}

This table reports the results from the second stage regression estimation of the two-stage estimation procedure described in Section 4. The dependent variable is company specific excess returns. The explanatory variables include a market return beta, and the betas of the Fama-French factors, and a liquidity risk beta. The underlying time period covers the years of 1905 to 1910 . The t-statistics are based on standard errors adjusted for heteroskedasticity and autocorrelation, and are reported in parentheses below the coefficient estimates. The symbols ***, ** and * indicate statistical significance at the $1 \%, 5 \%$, and $10 \%$ levels, respectively.

\begin{tabular}{ll}
\hline \hline Dependent variable & Company Excess Returns \\
\hline Market Excess Return & -0.0025 \\
& $(-0.24)$ \\
SMB & $-\mathbf{0 . 0 1 0 0}$ \\
& $(-5.98)$ \\
HML & $-\mathbf{0 . 0 2 2 0} 0^{* *}$ \\
& $(-2.14$ \\
Relative Bid-Ask Spread & $\mathbf{0 . 0 1 1 9}^{* * *}$ \\
& $(4.13)$ \\
Constant & $\mathbf{0 . 0 2 1 2}^{*}$ \\
& $(2.04)$ \\
\hline Observations & 185 \\
Adjusted $\mathrm{R}^{2}$ & 0.69 \\
\hline \hline
\end{tabular}




\section{Table 6.a: Determinants of Adverse Selection Costs}

This table reports the results of quantile regressions of adverse selection costs on a time indicator variable for the Panic period (October 1907 to January 1908) and controls for lagged monthly call money rates, monthly volatility, and lagged end-of-month share prices. The sample includes the panel of all traded NYSE stocks at monthly frequency from 1905 to 1909, and the table reports results for the 1st, 2nd, and 3rd quartiles. Adverse selection costs are denoted in percentage of stock prices and represent the part of relative spreads that is due to informational risk. Quasi-volatility is defined as the highest transaction price of a month minus the lowest transaction price of that same month, divided by the last transaction price of the month. T-statistics use heteroskedasticity-adjusted standard errors and are reported in parentheses below the coefficient estimates. The symbols $* * *, * *$ and $*$ indicate statistical significance at the $1 \%, 5 \%$, and $10 \%$ levels, respectively.

\begin{tabular}{lccc}
\hline \multirow{2}{*}{ VARIABLES } & $(1)$ & $(2)$ & $(3)$ \\
& ASC 1st quartile & ASC Median & ASC 3rd quartile \\
\hline \multirow{2}{*}{ Panic of 1907} & -0.0033 & -0.016 & -0.038 \\
L1.Stock Price & $(-0.46)$ & $(-0.74)$ & $(-1.36)$ \\
& $-0.000043^{* * *}$ & $-0.000060^{* * *}$ & -0.000065 \\
Quasi Volatility & $(-3.85)$ & $(-3.80)$ & $(-1.57)$ \\
& $0.0054^{* * *}$ & $0.013^{* *}$ & $0.015^{* * *}$ \\
L1.Call Money Rates & $(3.40)$ & $(2.52)$ & $(14.4)$ \\
& 0.0018 & 0.00013 & -0.018 \\
Panic of 1907 x L1.Call Money Rates & $(0.24)$ & $(0.0099)$ & $(-0.32)$ \\
& 0.067 & 0.32 & $0.90^{*}$ \\
Constant & $(0.46)$ & $(0.72)$ & $(1.59)$ \\
& $0.0090^{* * *}$ & $0.013^{* * *}$ & $0.018^{* * *}$ \\
\hline Observations & $(7.84)$ & $(7.62)$ & $(12.2)$ \\
Pseudo R ${ }^{2}$ & 1,506 & 1,506 & 1,506 \\
\hline \hline
\end{tabular}




\section{Table 6.b: Determinants of Inventory Holding Costs}

This table reports the results of quantile regressions of inventory holding costs on a time indicator variable for the Panic period (October 1907 to January 1908) and controls for lagged monthly call money rates, monthly volatility, and lagged end-of-month share prices. The sample includes the panel of all traded NYSE stocks at monthly frequency from 1905 to 1909, and the table reports results for the 1st, 2nd, and 3rd quartiles. Inventory holding costs are denoted in percentage of stock prices and represent the part of relative spreads that is due to inventory risk. Quasi-volatility is defined as the highest transaction price in a given month minus the lowest transaction price in that same month, divided by the end-ofmonth transaction price. T-statistics use heteroskedasticity-adjusted standard errors and are reported in parentheses below the coefficient estimates. The symbols $* * *, * *$ and $*$ indicate statistical significance at the $1 \%, 5 \%$, and $10 \%$ levels, respectively.

\begin{tabular}{lccc}
\hline & $(1)$ & $(2)$ & $(3)$ \\
VARIABLES & & & \\
& IHC 1st quartile & IHC Median & IHC 3rd quartile \\
\hline \multirow{2}{*}{ Panic of 1907} & -0.0037 & -0.0064 & -0.024 \\
L1.Stock Price & $(-0.62)$ & $(-0.84)$ & $(-1.14)$ \\
& $-7.0 \mathrm{e}-07$ & -0.000013 & $-0.000026^{*}$ \\
Quasi Volatility & $(-1.01)$ & $(-1.51)$ & $(-1.74)$ \\
& 0.0015 & $0.0078^{* * *}$ & $0.015^{* * *}$ \\
L1.Call Money Rates & $(1.49)$ & $(12.1)$ & $(26.2)$ \\
& 0.0043 & 0.0066 & 0.0087 \\
Panic of 1907 x L1.Call Money Rates & $(1.23)$ & $(0.62)$ & $(0.33)$ \\
& 0.085 & 0.12 & 0.47 \\
Constant & $(0.69)$ & $(0.79)$ & $(1.07)$ \\
& 0.000091 & $0.0037^{* * *}$ & $0.0087^{* * *}$ \\
\hline Observations & $(0.45)$ & $(3.52)$ & $(4.52)$ \\
Pseudo R & 1,506 & 1,506 & 1,506 \\
\hline \hline
\end{tabular}




\section{Table 6.c: Determinants of Order Processing Costs}

This table reports the results of quantile regressions of order processing costs on a time indicator variable for the Panic period (October 1907 to January 1908) and controls for lagged monthly call money rates, monthly volatility, and lagged end-of-month share prices. The sample includes the panel of all traded NYSE stocks at monthly frequency from 1905 to 1909, and the table reports results for the 1st, 2nd, and 3rd quartiles. Order processing costs are denoted in percentage of stock prices and represent the part of relative spreads that is due to costs of processing orders and market power risk. Quasi-volatility is defined as the highest transaction price in a given month minus the lowest transaction price in that same month, divided by the end-of-month transaction price. T-statistics use heteroskedasticity-adjusted standard errors and are reported in parentheses below the coefficient estimates. The symbols ***, ** and $*$ indicate statistical significance at the $1 \%, 5 \%$, and $10 \%$ levels, respectively.

(1)

(2)

(3)

VARIABLES

OPC 1st quartile OPC Median OPC 3rd quartile

Panic of 1907

0.0063

0.0020

$0.041^{*}$

L1.Stock Price

$(0.13)$

$-4.3 \mathrm{e}-06^{* *}$

$-0.000012^{* *}$

$-0.000020$

$(-2.18)$

$(-1.97)$

$(-1.34)$

Quasi Volatility

$0.0012^{* * *}$

$(10.1)$

$0.0021^{* * *}$

0.0072

L1.Call Money Rates

$-0.0046$

$(0.71)$

$(-1.43)$

$-0.019 * *$

$-0.041^{* *}$

Panic of 1907 x L1.Call Money Rates

$$
-0.12
$$

$(-1.30)$

$-0.021$

$-0.72^{*}$

$(-0.072)$

Constant

$0.0014^{* * *}$

$0.0045^{* * *}$

$0.0090 * * *$

Observations

$(5.38)$

Pseudo $\mathrm{R}^{2}$

1,506

$(6.80)$

$(4.82)$

1,506

1,506

Psendo $\mathrm{R}^{2}$

0.074

0.087

0.076 


\section{Table 7: Asset Pricing with Adverse Selection Risk}

This table reports the results from the second stage regression estimation of the two-stage estimation procedure described in Section 4 . The dependent variables are company specific average excess returns. The explanatory variables include a market return beta, adverse selection risk betas (measured according to Gehrig and Haas (2015) and set relative to stock prices, alternative measures of adverse selection risk betas (Kyle's lambda and the adverse selection measure of Hendershott et al. (2011))), an inventory holding risk beta (inventory holding costs relative to stock prices), an order processing risk beta (order processing costs relative to stock prices), and the the Fama-French factors betas, all of which were estimated in the first stage of the estimation procedure. The underlying time period covers the years of 1905 to 1910 . The t-statistics are based on standard errors adjusted for heteroskedasticity and autocorrelation, and are reported in parentheses below the coefficient estimates. The symbols $* * *, * *$ and * indicate statistical significance at the $1 \%, 5 \%$, and $10 \%$ levels, respectively.

\begin{tabular}{|c|c|c|c|}
\hline Dependent variable & Company Excess Returns & Company Excess Returns & Company Excess Returns \\
\hline \multirow[t]{2}{*}{ Market Excess Return (Gold Flow Rate) } & $0.00789^{* * *}$ & $0.00764^{*}$ & $0.00787^{* * *}$ \\
\hline & $(5.08)$ & $(2.08)$ & $(3.65)$ \\
\hline \multirow[t]{2}{*}{ SMB } & $-0.00117^{* *}$ & $-0.00341^{* * *}$ & $-0.00210^{* * *}$ \\
\hline & $(-2.29)$ & $(-5.11)$ & $(-3.81)$ \\
\hline \multirow[t]{2}{*}{ HML } & -0.000218 & $-0.00700^{* * *}$ & -0.000893 \\
\hline & $(-0.11)$ & $(-4.09)$ & $(-1.70)$ \\
\hline \multirow[t]{2}{*}{ ASC } & $0.00179^{* * *}$ & . & . \\
\hline & $(3.19)$ & . & . \\
\hline \multirow[t]{2}{*}{$\mathrm{IHC}$} & -0.0000421 & . & . \\
\hline & $(-0.17)$ & . & . \\
\hline \multirow[t]{2}{*}{$\mathrm{OPC}$} & $0.000346^{*}$ & . & . \\
\hline & $(1.90)$ & . & . \\
\hline \multirow[t]{2}{*}{ Kyle's Lambda } & $\cdot$ & 0.000000102 & . \\
\hline & . & $(1.20)$ & . \\
\hline \multirow[t]{2}{*}{ ASC (Hendershott et al. (2011)) } & . & . & $0.157^{* * *}$ \\
\hline & . & . & $(6.70)$ \\
\hline Observations & 126 & 166 & 164 \\
\hline Adjusted $\mathrm{R}^{2}$ & 0.29 & 0.67 & 0.40 \\
\hline
\end{tabular}


10 Online Appendix 


\section{Table 8: Low Call Money Rates and Relative Spreads During the Panic of 1907}

This table reports the results of quantile regression of relative bid-ask spreads on low call money rates and controls for volatility, share price, and panic indicator variables. The sample includes the panel of all traded NYSE stocks at daily frequency from August 1, 1907 to May 31, 1908 , and the table reports results for the 1st, 2nd, and 3rd quartiles. Relative bid-ask spread is the difference between ask and bid prices divided by the average of ask and bid prices. Quasi-volatility is defined as the highest transaction price on a given day minus the lowest transaction price on that same day, divided by the last transaction price (note that we exclude observations for which quasi-volatility is zero). The "Height of Panic" indicator variable takes the value of one during the height of the 1907 Panic, namely from October 22, 1907, to November 9, 1907, and zero otherwise. "Crisis" denotes the remainder of the Panic of 1907, namely the period of September 30, 1907, to October 21, 1907, and November 10, 1907, to January 31, 1908. T-statistics use heteroskedasticity-adjusted standard errors and are reported in parentheses below the coefficient estimates. The symbols ***,** and * indicate statistical significance at the $1 \%, 5 \%$, and $10 \%$ levels, respectively.

\begin{tabular}{lccc}
\hline & $(1)$ & $(2)$ & $(3)$ \\
VARIABLES & Rel. Spread 1st quartile & Rel. Spread Median & Rel. Spread 3rd quartile \\
\hline Height of Panic & $0.0030^{* * *}$ & $0.0072^{* * *}$ & $0.019^{* * *}$ \\
Crisis & $(3.00)$ & $(4.26)$ & $(3.95)$ \\
& 0.00015 & $0.0022^{* * *}$ & $0.0043^{* * *}$ \\
Low Call Money Rates & $(0.50)$ & $(3.72)$ & $(3.13)$ \\
& 0.0066 & 0.019 & $0.041^{*}$ \\
Stock Price & $(0.65)$ & $(1.44)$ & $(1.50)$ \\
& $-0.000059^{* * *}$ & $-0.000087^{* * *}$ & $-0.00012^{* * *}$ \\
Quasi Volatility & $(-4.29)$ & $(-4.15)$ & $(-4.25)$ \\
& 0.033 & $0.100^{* * *}$ & $0.28^{* * *}$ \\
Constant & $(1.32)$ & $(2.61)$ & $(6.68)$ \\
& $0.0081^{* * *}$ & $0.014^{* * *}$ & $0.023^{* * *}$ \\
\hline Observations & $(6.38)$ & $(7.08)$ & $(7.06)$ \\
Pseudo R & 12,180 & 12,180 & 12,180 \\
\hline \hline
\end{tabular}


Table 9: Descriptive Statistics of Betas of First Stage Regressions

\begin{tabular}{lcccccc}
\hline Variables & Mean & Median & Std & Q25 & Q75 & Observat \\
\hline \hline Table 5, column 1 & & & & & & \\
Beta Spread & & & & & & \\
Beta HML & -0.562 & -0.318 & 1.792 & -1.005 & -0.0573 & 185 \\
Beta SMB & 0.148 & -0.0108 & 3.564 & -0.291 & 0.359 & 185 \\
Beta Excess Market Return & -0.669 & 0.184 & 12.99 & -0.642 & 1.064 & 185 \\
& 0.714 & 0.596 & 2.572 & 0.280 & 1.056 & 185
\end{tabular}

Table 7, column 1

Beta OPC

Beta IHC

Beta ASC

Beta HML

Beta SMB

Beta Excess Market Return

$\begin{array}{cccccc}0.555 & 0 & 18.77 & -2.473 & 1.894 & 126 \\ 0.423 & 0 & 10.82 & -1.752 & 1.529 & 126 \\ -0.579 & -0.0409 & 6.890 & -1.888 & 1.133 & 126 \\ 0.380 & 0.245 & 5.303 & -0.326 & 1.097 & 126 \\ -1.714 & -0.315 & 19.96 & -3.566 & 0.380 & 126 \\ 1.288 & 0.692 & 2.615 & 0.379 & 1.459 & 126\end{array}$

\section{Table 7, column 2}

Beta Kyle's Lambda

Beta HML

$$
-3,520
$$

$-6.712$

16,007

$-815.0$

26.89

166

$-0.502$

$-0.158$

6.222

$-0.659$

0.544

166

Beta SMB

$-0.414$

0.462

15.04

$-1.194$

1.854

166

Beta Excess Market Return

1.274

0.873

3.046

0.520

1.490

166

\section{Table 7, column 3}

\begin{tabular}{lcccccc} 
Beta ASC (Hendershott et al. (2011)) & -0.00940 & -0.00888 & 0.202 & -0.0167 & 0.00846 & 164 \\
Beta HML & -0.670 & -0.195 & 7.902 & -0.775 & 0.143 & 164 \\
Beta SMB & -0.341 & 0.484 & 18.14 & -0.718 & 2.222 & 164 \\
Beta Excess Market Return & 1.223 & 0.938 & 4.076 & 0.541 & 1.436 & 164 \\
\hline
\end{tabular}

